\title{
Historical reconstruction and evolution of the large landslide of Inza (Navarra, Spain)
}

\author{
P. Sanz de Ojeda ${ }^{1} \cdot$ E. Sanz ${ }^{1} \cdot$ R. Galindo ${ }^{1}$ (D)
}

Received: 26 November 2020 / Accepted: 29 June 2021 / Published online: 8 July 2021

(c) The Author(s) 2021, corrected publication 2021

\begin{abstract}
In the winter of 1714-1715, a large rotational landslide originated on the northern slope of the Sierra de Aralar (Navarra, Spain), generating an earthflow that slowly descended through the valley for a kilometer and a half destroying the village of Inza. An interdisciplinary research recreated the historical process of the event and the geomorphological characterization of this large landslide. The geological analysis and hydrogeological characteristics of the site also identified the determining factors of this historical event. From the analysis that triggered the landslide and how the climate affected events can now be demonstrated from historical records of excess rainfall and the initial start of the process. From the recreated pre-failure topography, the stability of the original slope was studied using a 3D numerical model to identify the factors, causes and mechanism that controlled the development of the landslide.
\end{abstract}

Keywords Historical landslide $\cdot$ Groundwater $\cdot$ Rotational landslide $\cdot$ Retrospective modeling $\cdot$ Numerical simulation

\section{Introduction and objectives}

As it is well known, slope processes are geomorphological activity but also manifestations of environmental change and territorial threat. Within global change, these processes respond to natural factors but also to anthropic uses and practices. Lithology and mountainous relief, among others, are the main conditioning factors that cause failures. Regarding the triggers of the slope processes in areas of moderate or reduced seismicity, the climate exerts a first-order control. In the north of Spain, the main cause of the trigger process is precipitation (Corominas 2006; Díaz et al. 2012). Analyzing and establishing the relationship between precipitation events and the appearance of instabilities together their evolution aided by modeling is also the object of important research (for example, Vassallo et al. 2015; Valenzuela et al. 2018).

R. Galindo

rubenangel.galindo@upm.es

1 Departamento de Ingeniería y Morfología del Terreno, Escuela Técnica Superior de Ingenieros de Caminos, Canales y Puertos, Universidad Politécnica de Madrid, Madrid, Spain 
Indeed, the greater the intensity of the rain, the more the pore pressure of the water in the soil increases, thus decreasing the resistance to shear. This relationship between past and current climates with the occurrence of landslides has been discussed by various authors: Starkel (1966), Cendrero et al. (1994) and González-Díez et al. (1996) who relate the occurrence of landslides in northern Spain with the evolution of the climate as the most likely triggering factor. They identified, for example, a higher frequency of landslides with increased rainfall at the end of the Little Ice Age. They also showed how, in the past 25 years, $60 \%$ of the movements were caused by three rainy episodes: 1983 , 1992 and 1994. Gallart and Clotet (1988) and Domínguez et al. (1999) also observe this relationship between rainfall and landslides in the north of Spain. They reported how, during the period 1980-1995, almost $80 \%$ of the landslides were associated with years of rainfall of more than $1000 \mathrm{~mm}$ that fell between December and April.

The study of the relationship between climate and major landslides helps address various aspects of mountain areas (Corominas and Moya 1999; Corominas et al. 2005; Corominas 2006): the analysis of recent and past major landslides can provide the means to anticipate any recurrence in the future.

Landslides can also be used as geoindicators of climate variations. Some authors suggest, for example, that the frequency of landslides may have been higher during the Little Ice Age since the weather conditions were wetter (Grove 1972).

But the relationship between climate and the triggering of major historical landslides is complex, since these have a behavior highly dependent on the geological-geomorphological context in which they occur. This is why it is very important to carry out detailed studies to learn more about the breakage mechanisms and the causes that generated them. A good characterization of a landslide includes adequate interdisciplinary research and some good examples of monographic studies of large landslides, and the different methodologies can be found in the works of Lomoschitz et al. (2002), Borgatti et al. (2006), Zarroca et al. (2014), Cruden et al. (2014), Bièvre et al. (2016), Mihalić et al. (2017) and Burda et al. (2018), among others. Retrospective modeling can also help identify the factors and causes that controlled the development of the landslide (back analysis). This requires recomposing the initial topography as it was before the breakage. Several authors have used different methodologies and applied different criteria for the three-dimensional reconstruction of the topography (e.g., Sturzenegger et al. 2014, Sanz et al. 2016).

In the mountainous area of northern Spain, landslides are a recurring phenomenon that has been documented for several centuries. The case of the 1714 Inza landslide, which is studied here, is probably one of the oldest documented historical events.

Inza is a small village of 60 inhabitants that is part of the municipality of Araiz, in the north of Navarra (Spain). It is located on the northern slope of the Sierra de Aralar at an altitude of $321 \mathrm{~m}$ (Fig. 1), where the Araiz Valley extends, at the foot of Mount Irumugarrieta $(1427 \mathrm{~m})$. In the winter of 1714-1715, now more than 300 years ago, Inza was affected by the consequences of a landslide. This rotation-type landslide originated at the foot of mountains, generating a glacier-like earthflow that flowed slowly through a thalweg destroying Inza a kilometer and a half below. The village was rebuilt nearby to the current location outside the thalweg, thus changing its previous physiognomy.

The main historical information about the Inza landslide was a review by Eloségui (1976), and the study of this landslide was started by Aparicio et al (1987). Based on the knowledge of these two authors, in the present study are applied new prospecting and interdisciplinary research that has expanded our knowledge of the event.

The present research work had the following objectives: 
(A)

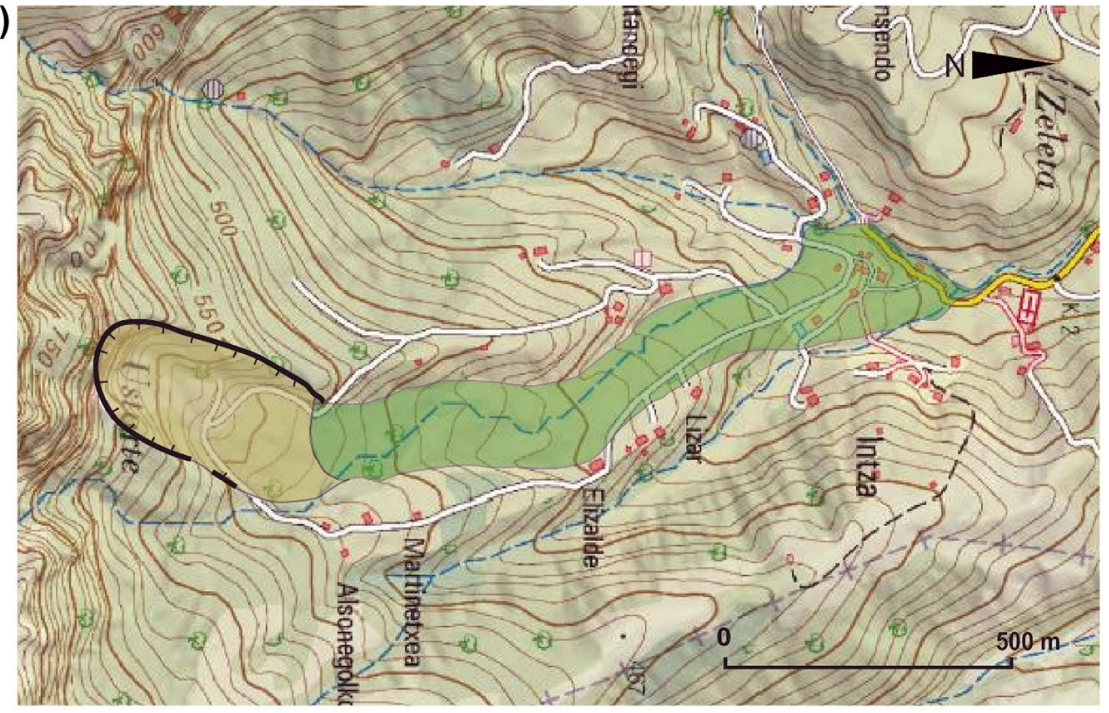

(B)

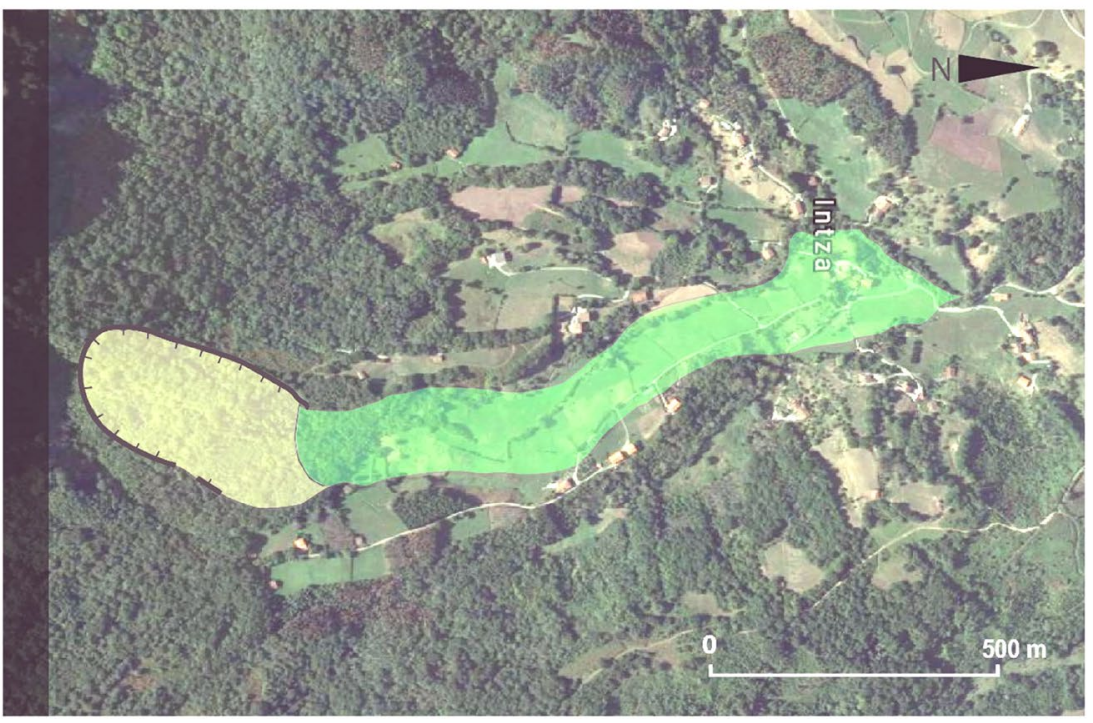

Fig. 1 Location of the study area: a Current boundaries of the landslide are indicated on a topographic map of the area. $\mathbf{b}$ Landslide on an aerial photograph

- Characterization of this large landslide from the geomorphological perspective and the analysis of the geological and hydrogeological characteristics of the site as conditioning factors.

- Analysis of the triggers of the landslide and how the climate affected the landslide, by studying the relationship between the historical records of excess rainfall and the appearance of the trigger process.

- Reconstruct the history and evolution of the 1714-1715 landslide. 
- Evaluation of the stability of the original slope where the landslide was formed using a numerical model to identify the factors, causes, and mechanism that controlled the development of the landslide (back analysis).

- Activity after the 1714-1715 landslide.

\section{Methodology}

\subsection{Historical survey}

The historical reconstruction of the beginning and evolution of this landslide are based on the oral tradition that still exists in the area through oral communication with inhabitants of Inza (Zubiri, 1974). But the main information is found in various written documents from the time and collected by Eloségui (1976), including the Parish Archive of Inza, General Archive of Protocols and Diocesan Archive of Pamplona, and other historical sources of information (Lopez-Sellés 1974; Zubiri 1977; Esparza 2002; Tarifa Castilla 2008). Heavy rain was the origin of the instability, but since rainfall records were not kept at the time the records of rogation ceremonies were used that did include information of drought or excessive rain. These rogation ceremony records are kept at the cathedral of Santo Domingo de la Calzada, which date back from the sixteenth, seventeenth and eighteenth centuries (Sáez de Ocáriz 1990). This area is part of La Rioja and is close enough to the study area to consider the information valid. La Rioja corresponds to the same diocese as Guipúzcoa, a province that borders Navarra where Inza is located. The rogation ceremony records are the most complete records available from cathedrals near the study area.

Inza is a humid area and does not usually suffer from droughts. But the damage to crops or farming is not only due to droughts, but also to excessive rains, and this is what is analyzed from the record of rogation ceremonies that are presented here. There is also damage from excessive rainfall in humid areas, for example: flooded meadows, potato crops that have rotted from excess humidity, etc. The rainfall pattern in Santo Domingo de la Calzada is conditioned by the rain fronts from the NW, from the Atlantic, which is the same as in Inza. In addition, Inza belonged to the diocese of Santo Domingo de la Calzada, and the record of rogation ceremonies was for all population of the diocese.

\subsection{Geological and geomorphological survey}

A geomorphological and geological cartography survey at a scale of 1:5000 was carried out by means of field characterization and interpretation of aerial photographs at 1:5000.

\subsection{Geophysical survey}

To ascertain the nature and thickness of the sliding mass that is from longitudinal profile to the slide area (Aparicio et al. 1987), information was available (Figs. 2 and 7a) from electrical resistivity and seismic refraction tests. 


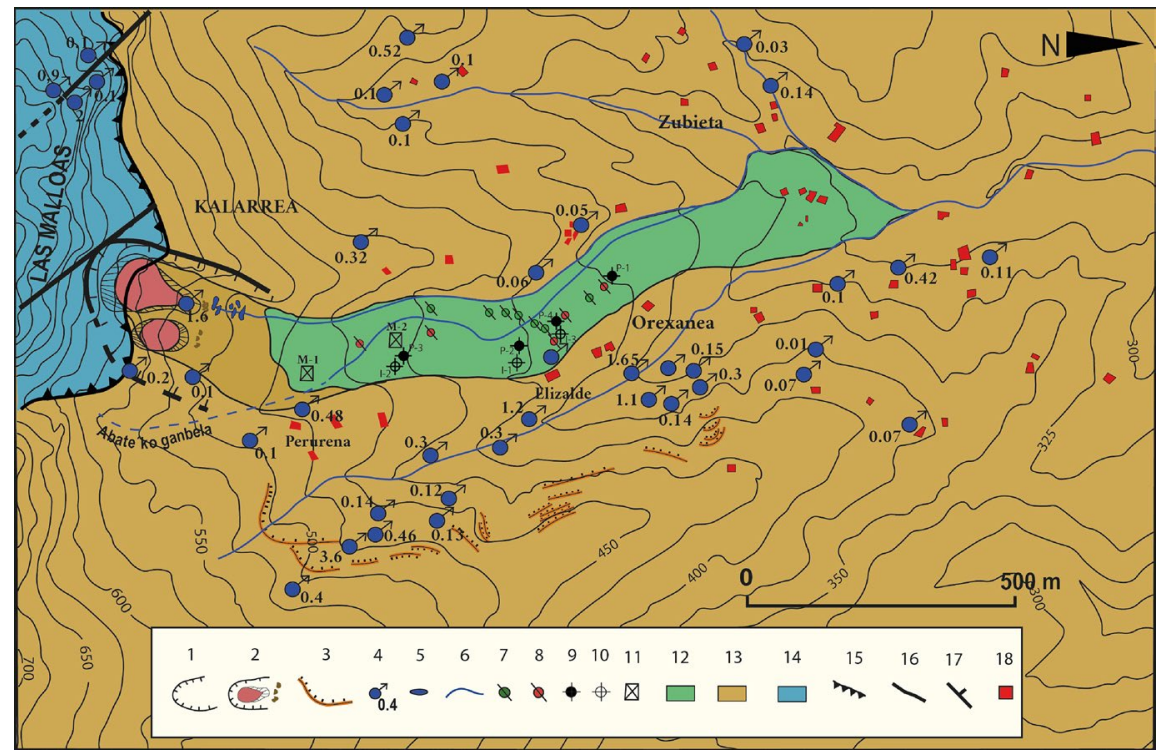

Fig. 2 Geological map of the Inza landslide at present: 1. Head scarp of the landslide of 1714; 2. Landslide and fallen blocks of 1984; 3. Tensile cracks; 4. Springs (flow in L/s during 2018 low water); 5. Ponds at the head of the landslide; 6. Streams; 7. Vertical electrical soundings (VES); 8. Seismic refraction surveys; 9. Piezometers; 10. Inclinometers; 11. Block sampling in pits. 12. Slide mass; 13. Slates and siltstones; 14. Limestones; 15. Overthrusting; 16. Faults; 17. Strike and dip; 18. Hamlets

\subsection{Landslide activity and movement control after 1714}

The study of these processes combined in situ recognition and auscultation techniques, while temporal analysis was required to use digitized aerial photographs and orthoimages. Thus, to know the latent and residual activity of the scarp that dominates the head of the landslide as well as of the earthflow, the stereoscopic analysis was quite useful to interpret the 1:5000 aerial photography sequences that have been available since 1929 (1929-1945-1956-1973-1998-2005-2010-2014-2019) (IGN). This made it possible to identify any variations in the boundaries of the meadows and in the cadaster, which were complemented and confirmed with historical information and testimonies from the inhabitants of the area. These displacements have been roughly measured considering the hamlets around the landslide as stable reference points and seeing how the boundaries of the meadows moved in the photographs at different dates. Information from three boreholes drilled with rotary percussion distributed along the sliding tongue (Figs. 2 and 6b) until the Orexanea hamlet-which is the lowest point where movements were observed (DOPGN 1999, 2000)-it was possible to quantify: the current land movement, the detection of the failure surface and the speed and direction of the earthflow. These boreholes were located in the low, intermediate and high zones of the landslide, with depths of 40, 20.6 and $26.7 \mathrm{~m}$, respectively. An inclinometer pipe was installed in 1999 and 2000 with readings for 12 months following their installation. 


\subsection{Geotechnical survey}

The available geotechnical information includes:

1. The information (Aparicio et al. 1987) from electrical resistivity and seismic refraction tests and some pits manually excavated in the sliding mass (Figs. 2 and 7a). Geophysical profiles were used to detect the thickness of the sliding mass, the seismic velocities of each layer and the rocky substrate.

2. There are six rotary boreholes with a continuous core recovery for piezometers and inclinometers (Figs. 2 and 7a). In four of the boreholes, unaltered samples were obtained for geomechanical characterization. The following laboratory tests were carried out on the undisturbed samples taken during the drilling of the boreholes: 9 Atterberg limits, 4 water content, 4 dry and wet densities, 6 granulometries and 1 direct shear test with peak and residual friction angle.

\subsection{Hydrogeological survey}

An inventory was carried out of the existing water points in the area to establish the current hydrogeological conditions of the landslide: springs, lagoons and streams with permanent water, including flows and ephemeral points in the slide area and its surroundings. In addition, information from four piezometers was also available (Fig. 2). The limestone mass at the head of the landslide was also investigated to better understand the current hydrogeological function of the karst, which is important for inferring the initial hydrogeological conditions before the breakage of this landslide. This inventory is the result of the field visit on different dates. The approximate flow was measured with a bucket and in regular sections with a float, and the water temperature was measured with a field thermometer. The rate of variation of the flow of some karst springs was not measured regularly, but sporadically.

\subsection{Landslide simulation}

Prior to the simulation, the pre-slide topography was reconstructed in 3D which, although it has a certain degree of subjectivity, provides sufficient detail for modeling purposes. The steps followed for the reconstruction of the topographic and geological profile are explained in Sect. 4.5, but first it is necessary to explain the geological and geomorphological characteristics of the site.

Once the pre-failure topography was recreated, it was studied for stability using a 3D model with the software FLAC3D (Fast Lagrangian Analysis of Continua), a software developed for the geotechnical calculation by ITASCA group. It is based on the method of finite differences, which allows the use of nonlinear behavior laws, with an explicit resolution scheme of the differential equations of the geotechnical problem. Although the medium was divided into elements formed by quadrilaterals, FLAC internally divides the quadrilateral into two superimposed groups of triangles of constant deformation of triangular elements.

The back analysis of the landslide has to include two distinct phases. First, the original landslide of 1714 that occurred in the head scarp must be simulated, and in the second stage of the analysis, the simulation was carried out as an earthflow over the Araiz Valley derived from the original sliding mass. 


\section{Site description}

\subsection{General description}

The Inza landslide is located at the foot of the northern slope of the Sierra de Aralar (Navarra, Spain) (Fig. 1). The landslide currently fills the thalweg of the Ycibar stream, which has its origin in several small springs located in the upper surface of the landslide, in contact with the limestone of the Sierra. The thalweg of this stream converges one and a half kilometers downstream, in the village of Inza, with two other thalwegs to the right and left, which also start in the Sierra de Aralar (Fig. 1). The Ycibar stream is a tributary of the Araxes river.

To the north of Inza lies the Araitz valley, carved out of the marly sediments from the Cretaceous period. The northern slope of this mountain range presents a steep front, cut by vertical cliffs and a strong topographic unevenness, Urgonian limestone rocks, known as Las Malloas. The difference in height between the summits of Aralar (Aldaon $1410 \mathrm{~m}$ ) and Irumugarrieta (1430 m, the highest point in the Sierra) reaches a difference in height of more than $1000 \mathrm{~m}$ relative to the head of the valley.

Regarding vegetation, natural forest masses gone through a considerable regression due to the increase in the surface area of meadows and pastures, covering the Araitz valley and the mountain slopes. In the Sierra de Aralar, and above 600-800 m, calcareous beech forests predominate. All over the Aralar foothills there are mixed hardwood forests with pedunculated oak dominates, mixed with ash trees, hollies, chestnuts and mountain elms in the transition to beeches.

In a broad sense, the region has a temperate oceanic climate (type $\mathrm{Cfb}$ according to Köppen 1936) and does not have a marked dry season, presenting a fairly homogeneous distribution of rainfall throughout the year. However, there is an absolute maximum during the late autumn and early winter months (a reminder that the Inza landslide occurred in December) and a relative maximum in spring in April, as well as an absolute minimum in summer. The climate is hyper-humid, with rainfall exceeding $2500 \mathrm{~mm}$, making it one of the rainiest areas on the Iberian Peninsula and Europe (Lozano 2006). In the area of study, the climate is oceanic in the lower parts and with mountain climate features in the higher areas. Rainfall is abundant and regular during all seasons. The $1600 \mathrm{~mm}$ fallen in the valley increases until widely exceeding $2000 \mathrm{~mm}$ in the highest peaks due to the orographic effect on the masses of humid air. In winter, there is a lot of snow on Las Malloas, creating favorable conditions for the collision of the fronts coming from the Atlantic and where fog is very frequent. The average annual temperature is around 12 degrees Centigrade, while in the higher parts it drops considerably to below 7 degrees Centigrade. However, referring to an average year, there is no dry period or water deficit in the soil for plant growth.

\subsection{Site geology}

The entire northern slope of the Sierra de Aralar is made up of Cretaceous slatey siltstones ("Black Flysch" of the Albense stage), where the predominant discontinuities are stratification versus schistosity. The stratification has a direction of $225^{\circ}-260^{\circ}$ and a dip that varies between $50^{\circ}$ and $72^{\circ}$ to the north, against the slope (Fig. 2). Therefore, both the strike and the dip do not follow the direction of the slide mass, which goes down the slope following the direction of a south-north thalweg. 
At the top of the slope is the Cretaceous reef limestone cliff of Las Malloas of the Sierra de Aralar (Fig. 3). The limestone layers are in a NW-SE direction and dip to the SW, also against the slope. The contact is by a reverse fault, where the limestone is placed on the slates (Fig. 2). This contact is masked by the filling of debris and boulders and colluvial material. The limestone has a NW-SE direction and dip to the SW. Above this limestone, there are three other similar contacts between Jurassic-age carbonate rock formations, in the form of flakes within the front of the reverse fault. The tectonized zone of the thrust front in Las Malloas presents a system of large vertical fractures of SE-NW and SW-NE orientation, which opens up in the vicinity of the cliff; in addition, there are other mechanical stress fractures. Between some layers there are large cracks, some of which store water. There are also chasms in the aforementioned fractures at the upper edge of the cliff (Galán et al. 2019).

The Cretaceous period is made of massive gray reef limestone that is highly recrystallized and has a thickness of about $500 \mathrm{~m}$, sometimes interspersed with marly limestone. They correspond to the Albian-Áptian stage. The Jurassic period is formed by dolomitic limestone banks, with fine interspersed marls and limestone marls. The observed maximum thickness ranges from around 170-200 m, which somewhat low for this study area. The era of this limestone is between the Bajocian and the middle Callovian.

In the different thalwegs that descend from the Sierra de Aralar, erosion predominates in the streams that lack alluvial deposits. This also occurs in the valley of Inza, which was

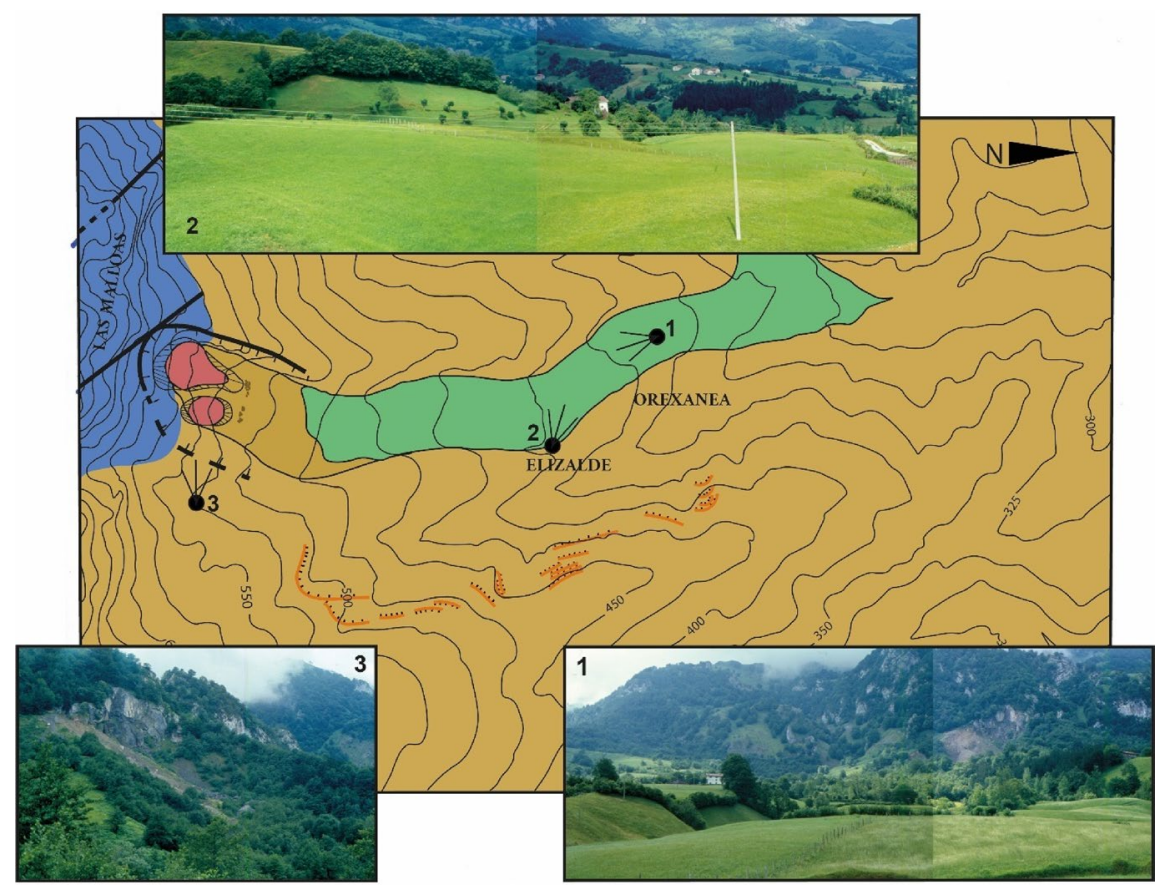

Fig. 3 Photographs of the Inza landslide: 1. Thalweg filled by the earthflow from 1715, vegetation around curved meadows. Upstream, can be seen the Las Malloas in the Sierra de Aralar in the old head area of the rotational movement; 2 . In the foreground, meadows in the filling and the slope of the substrate on the left bank; 3. Detail of a small rockfall that occurred in 1984 in the old main scarp at the head of 1715 
confirmed downstream from the front of the earthflow and through boreholes that were drilled across the mass of the ancient slide tongue. On the slopes at the foot of Las Malloas, and in general throughout the surroundings, the slatey substrate was weathered to a depth of $1.5 \mathrm{~m}$. In this layer of alteration, the debris of slate is arranged parallel to the predominating slope. Sometimes there are levels of black clay interspersed due to alteration of the more clayey limonites in the substrate, which is associated with confined water. At the top there is a layer of clayey soil and topsoil with abundant organic matter. Together, all of this forms a very slippery layer. In fact, around Inza there are other unstable shallow areas that seem to be associated with this layer of alteration, which are present in the scarps that appear in the meadows as shown in Fig. 2; this is the reason why there are cracked hamlets.

\section{Results}

\subsection{Historical survey}

There are three aspects where historical research can be an especially useful tool:

- Find out whether there were any previous instabilities. This is a secondary issue because from the geomorphology perspective it is almost certain that there were no instabilities during the recent epoch.

- Relate the chronology of events about the origin and evolution of the landslide during $1714-1715$.

- Get a sufficiently reliable climate record for the past few centuries.

\subsubsection{Evidence of instability before 1704 at Inza}

As will be seen in the section on Geomorphology, it is very likely that this landslide was the only event of this magnitude that occurred recently, but since this village was destroyed by it, finding out the age or foundation of the village of Inza would provide a reliable minimum period of inactivity. According to GEN (1999) and other references (Esparza 2002, Lopez-Sellés 1974), Inza was a place of royal lordship, whose annual tribute in 1280 amounted to 96 salaries. The Hospitallers of St. John of Jerusalem owned some heritages within its boundaries since the thirteenth century. Probably the hermitage of Santa Cruz is from that period, it was already mentioned in 1569 and of very old construction (LopezSellés 1974). The monarchs Juan III and Catalina granted their neighbors (1507) the privilege of collective nobility (Esparza 2002). Thus, the origin of Inza could be established no later than the twelfth century. Therefore, for a period of 500 years prior to the 1714-1715 event there were no landslides in any of the three thalwegs that converge in the village.

\subsubsection{On the origin and evolution of the 1714 landslide}

4.1.2.1 Chronology of events The beginning and some phases of the evolution of the landslide can be deduced from the interpretation of the historical sources of information. The following chronology of events is reported below (Fig. 4): 
Fig. 4 Origin and phases of evolution of the Inza landslide tongue during 1714-1715: A Situation prior to the landslide. The rainfall of the previous months increased the number and flow of the springs in the limestone-slate contact under Las Malloas de Aralar in Inza and those associated with the NW-SE fault. The resulting water flows soaked the slate on the slope by increasing pore pressure. B Triggering of a rotational landslide in the slates at the end of December 1714 which breaks the slate from the aforementioned water-conducting fault. Formation of an earth lobe that closes the right lateral thalweg that retains water from springs and streams. C The accumulated water forming two dam lakes, and on January 20, 1715, the earthflow began to move. D First days of February 1715, the earthflow arrives at the hamlet of Elizalde. E. Terminal evolution, between 20 February and the end of April 1715: (a) On February 20, 1715, most of the hamlets were destroyed and the front of the landslide was $25 \mathrm{~m}$ from the church; (b) on March 5, the church was in danger of being ruined. Twelve houses in the village were destroyed. The tongue overflowed from the right and left side thalwegs; (c) on 29 March the church was completely destroyed; (d) on April 3, 38 houses in the village were destroyed, including the abbey house; (e) at the end of April, the movement had stopped. F. Distribution of the speed of the earthflow according to a time frame

- The event started at the end of December 1714, after very rainy months of August and September 1714 and during the winter (Eloségui 1976), that triggered a landslide on the slopes of Las Malloas de Inza.

- According to historical documents provided by Eloségui (1976), the landslide originated at the end of December 1714 and produced a giant elongated spoon-shaped concavity on the mountainside that was previously unknown, causing the rocky limestone cliffs of Las Malloas to fall. In the lower contact between the permeable limestone and the impermeable slatey base, there were (and still are) numerous springs that gave rise to the Ycibar stream which runs through the Inza valley which drives the local mill.

- The slide mass caused a depression at the head of the landslide where the water of the stream accumulated forming a lagoon (Fig. $4 \mathrm{~b}$ and c) that closed the course of a tributary stream running down from the area called Abate'ko Ganbela $(1020 \mathrm{~m})$. A lateral lagoon was formed that even at present is reduced to a waterlogged area of $100 \times 20 \mathrm{~m}$ (Eloségui 1976).

- According to the report prepared by the military engineer Hercules Torrelli (Eloségui 1976) who visited the site in February 1715, the earthflow began on January 20, 1715. This glacier-like flow of mud advanced slowly but continuously and filled in the old Ycibar valley, which it flooded but did not overflow through the dividing lines, except for the final part. The earth mass rose in its intermediate section to the level of some hamlets located halfway up the slope, and the flow was significant enough to partially destroy the buildings, as in the case of the Elizalde hamlet where the bakery was destroyed. This hamlet is still inhabited at the present (Fig. 4d).

- On February 20, 1715, the situation was: a large part of the hamlets were destroyed by the earthflow, pushing the houses forward and then burying them. The fifteenth century church, located about $1300 \mathrm{~m}$ away from the head of the landslide, was still intact, but the front of the landslide was very close (less than $25 \mathrm{~m}$ ). It was recommended that the church be dismantled and move the altarpiece to a safe location.

- On March 5th, the church and the abbey house, specifically from the foundation to the vault, were in danger of eventual collapse. The altarpiece was moved in pieces to the nearby hermitage of Santa Cruz (Tarifa Castilla 2008). In all, twelve houses were ruined and made uninhabitable.

- According to Eloségui (1976), the tongue of the landslide must have overflowed along the dividing line of the right bank, in the lower part that corresponds to the area of the village (Fig. 4e).

- On March 29th, the church was completely destroyed. In addition, the Royal Road that was used at least since the sixteenth century was, in this stretch, filled by the landslide. 
(A)

(B)

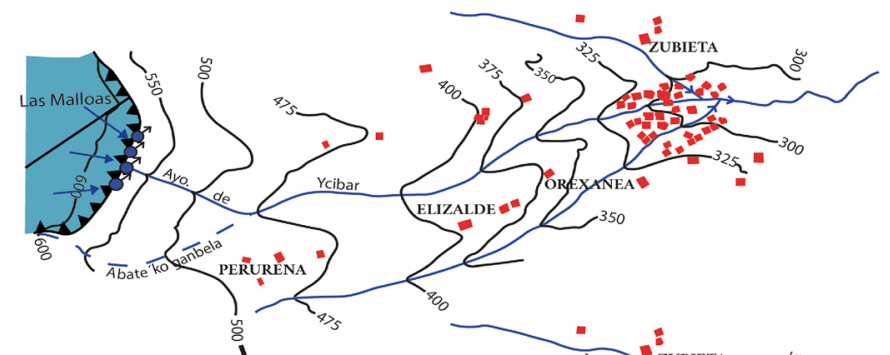

(C)

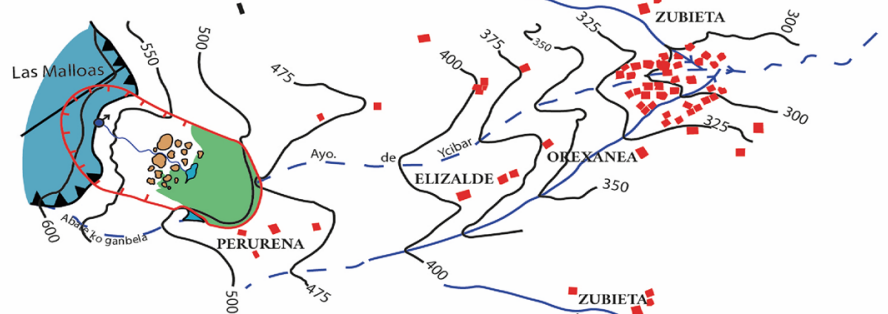

(D)

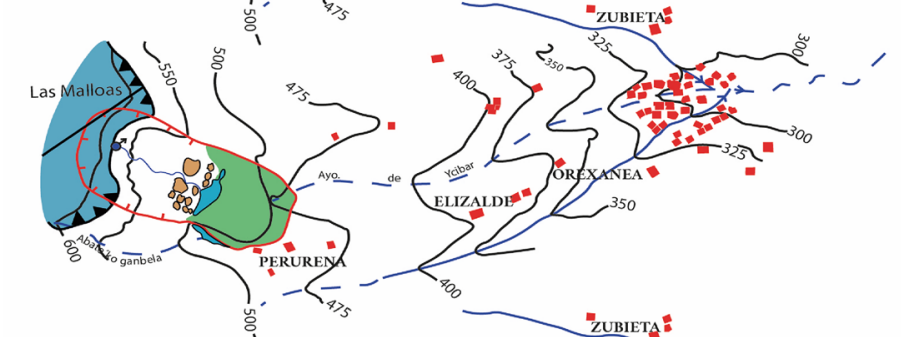

(E)

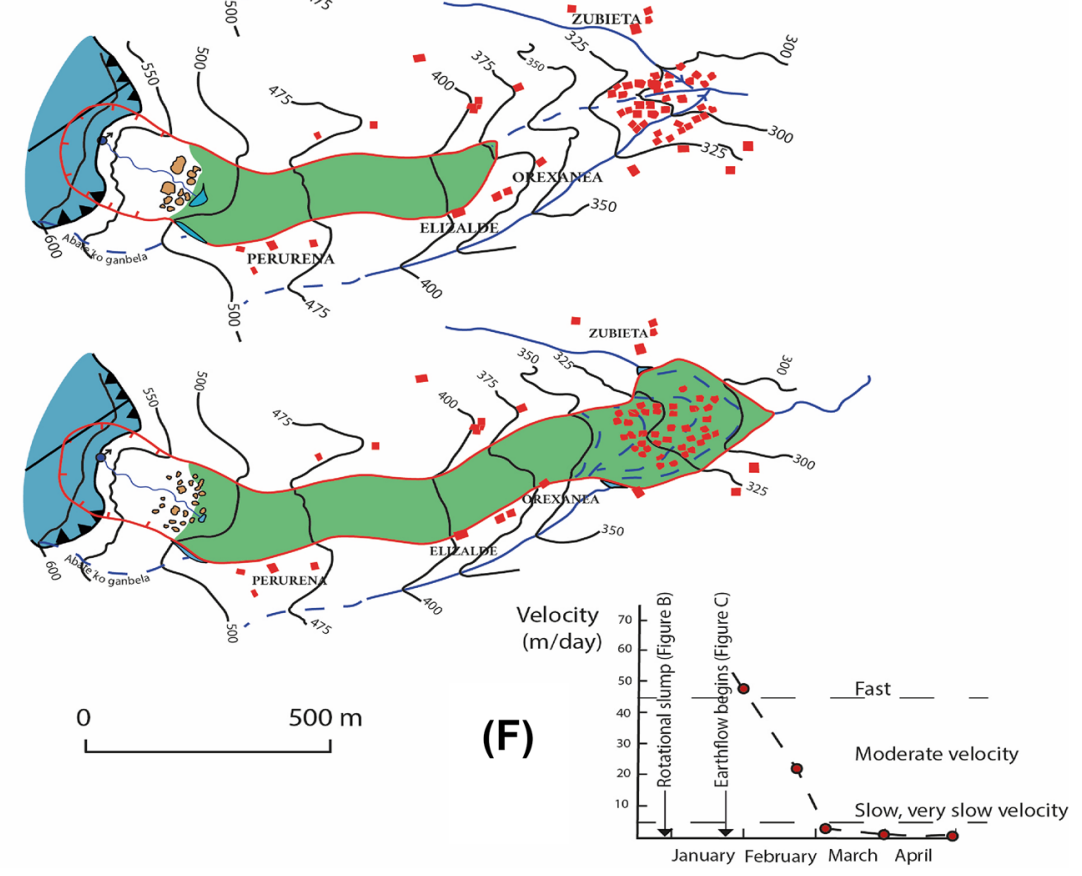

- According to Eloségui (1976), the abbey house was destroyed on April 3, 1715. On this date, 38 houses were totally destroyed, the abbey house and the church of San- 
tiago, the mill, the town hall and the washhouse (Fig. 4e). There were 30 houses that were not affected because they were more dispersed or out of reach of the tongue of the landslide. The landslide did not result in any human casualties. The people had enough time to dismantle the roofs and use the wood and collect the fruit from the trees and the vegetable gardens. They took refuge and began to repair and erect new buildings in safe places, thus giving a new configuration of the Inza village, which still stands today. It seems that at the end of April the movement was no longer active. Work on the new parish began in 1716 and was mostly completed by 1721 (Tarifa Castilla 2008). By October 1718, 12 new houses were built, and in 1718 the new mill was built. By 1721 the town hall was built and by 1725 the current church of Santiago was finished.

There were other events of rockfalls from later years noted below although they were different events from the earthflow:

- On April 11, 1966, another huge rock from Las Malloas of $6000 \mathrm{~m}^{3}$ (Eloségui 1976) fell off, causing alarm in the hamlets of the area. In previous years, small movements were observed in this rocky sector until this large rockfall occurred.

- In 1999, there was also a small rockfall.

4.1.2.2 Evolution of the landslide in the months after the failure This chronology of events allows us to establish that the landslide produced an instantaneous drainage of water stored in the limestone aquifer, which contributed to increase the humidity of the detached soil. But in addition, the water drained by the spring accumulated in a barrier lake that formed the detached lobe. The water could not escape by draining off into the adjacent thalwegs, so it seeped into the sliding marly mass, which became soaked in water, increasing its fluidity and specific weight. The fact is that when the limit of plasticity was exceeded, after 20 days, the fluid mass, helped by the slope, was redirected as a flow of mud invading the valley of Inza. Thus, the material became soft and the body of the earthflow slowly deformed, or failed along multiple shear surfaces, producing lobate, flow-like morphology.

Acceleration occurs when the source slide becomes destabilized, by a temporary increase in pore pressure. As material in any part of the earthflow tongue accelerates, it over-rides or compresses soil masses downslope, increasing pore pressure through undrained loading (Hutchinson and Bhandari 1971). In this way, a kinematic wave propagates through the soil mass, to advance the toe into a stream, a water body, or another erosion sink. If instead of a thalweg there was an open area, probably there would not have been an elongated and expanded tongue produced, and the movement would have been less. It can be assumed that this same earthflow would have unclogged the dam, thus emptying the lagoon very slowly. Even today, as already mentioned, and during minor destabilizing events, there is a certain tendency to form pools and ponds of water.

This earthflow filled the bottom of the thalweg to half a slope at a height of between 10 and $30 \mathrm{~m}$, but without overflowing the dividers. According to the historical chronicle, it was possible to know the advance and deceleration of this tongue, as shown in Fig. 4 . The flow ran at a rapid speed, more than $50 \mathrm{~m}$ /day (Cruden and Varnes 1996) until early February 1715, when it covered just under half of the path. Then, it continued with a moderate movement around $22.5 \mathrm{~m} /$ day until the beginning of March, when it had already reached the village. Until the end of April when the movement stopped completely, the speed decreased progressively (3.6-0.83 m/day) in a slow-to-a-very-slow movement (Fig. 4c). Its 
highest speed was in the middle, due to friction of the slopes, as in a rocky glacier, that is why the contours are concave upstream.

According to the reconstructed topography of the bottom of the thalweg, the slope is about $13^{\circ}-14^{\circ}$ and remains more or less constant from the foot of the landslide to the village. Also, the section of the valley does not vary substantially until the confluence with the other two thalwegs in the lower part. This locality is at a crossing between three valleys that caused the maximum expansion and accumulation of more than $30 \mathrm{~m}$ of the ground mass, as well as its deceleration. This expansion temporarily blocked a lateral thalweg in the lower area, and the subsequent erosion prevented the formation of a lagoon that would probably have formed there. The deceleration of the movement was mainly due to the decrease of the head thrust of the foot of the earth as it spread through the valley, to the drainage of the mass of earth, and to the increase of the section at the bottom. In its displacement, it pushed and buried the houses of the Inza village, which it slowly destroyed: these village houses can be considered the resistance to the advance of the earthflow. In any case, at an average speed of $8 \mathrm{~m} /$ day, this movement is classified as slow according to Cruden and Varnes (1996). This slow movement is in accordance with the not too clayey nature of the flow mass, not to mention that it took more than 20 days for the water saturation to set the landslide in motion. During slow, steady motion phases, the deformation may be concentrated on the main shear surface, analogous to a translational slide.

\subsubsection{Reconstructing the climate in recent centuries}

In the absence of historical pluviometric records from that time and previous centuries, Fig. 5 shows the months of rogation for drought or excessive rainfall in the sixteenth, seventeenth and eighteenth centuries from the archives of the cathedral of Santo Domingo de la Calzada (Sáez de Ocáriz 1990).

As can be seen in Fig. 5, 1714 is the year with the highest number of months of rogations due to excess rainfall during these three centuries. In fact, it is quite rare for there to be three months of rogations in a year, with one, two or none being normal. It was also four months with persistent rain in a row before the landslide occurred: July, August, September and October.

In this area, the months with the highest rainfall records are currently November, December, January and April, with persistent rainfall. It should also be noted that in the daily records with values greater than $60 \mathrm{~mm}$, they also occur in other months, mainly in August and September (Uriarte 1996).

\subsection{Surface and deposit morphology}

According to the boreholes and prospection carried out, the slide mass was made up of a heterogeneous mass in which fragments of gravel-sized slate mixed with a clayey matrix predominate, although there was also an abundant slate pebbles, limestone and coarse and boulders of limestone. The thickness depends mainly on the geometry of the valley floor, so that in the transverse direction, it acquires the maximum relative thickness in the center. The thickness increases in a longitudinal direction from the head of the earthflow to the lower part where it exceeds $30 \mathrm{~m}$. It can be seen that this lower part is where more mass was accumulated during the months that the landslide lasted. 
Fig. 5 a Distribution of the frequency of rogations due to drought and excess rainfall during the seventeenth, eighteenth and nineteenth centuries in the Cathedral of Santo Domingo de la Calzada; $\mathbf{b}$ in greater detail, the frequency of excess rainfall during the eighteenth century is shown

The geomorphological description corresponds to the current state, although observations from earlier times were made using aerial photographs and information collected in the field and testimonies from local people.

As already mentioned, this landslide is located on the northern slope of the Sierra de Aralar, at the foot of the rocky cliffs of Las Malloas de Inza. The root of the landslide head is located at $600 \mathrm{~m}$, and the front at $277 \mathrm{~m}$, with a height difference of $323 \mathrm{~m}$. Its longitudinal development is $1450 \mathrm{~m}$. Following the terminology of Dikau et al. (1996), Table 1 shows the dimensions of the landslide. This huge landslide was $1450 \mathrm{~m}$ long, of which about $350 \mathrm{~m}$ corresponds to the visible part of the rotational landslide of the head and $1100 \mathrm{~m}$ to the tongue of earthflow that originated later, filling in the valley where it was constrained, with an average width of some $230 \mathrm{~m}$. The foot of the original landslide is now hidden under the accumulated landfalls. Most of the tongue is preserved except in its terminal part where the ground glacier overflowed the dividers and invaded the adjacent thalwegs before the confluence of the three streams. The erosion of these two lateral streams during and after the initial phase of the movement destroyed a small part of this tongue, which is shown reconstructed in Fig. 2. This landslide involved at least more than 1.5 million $\mathrm{m}^{3}$ with an average slope of about $30^{\circ}$ at the head, and $11^{\circ}-12^{\circ}$ at the tongue. The transversal profile is concave at the head and slightly convex upwards on the tongue.

The upper part shows an old slope resulting from a rotational landslide that is currently hidden by the scrub forest, which was partially destroyed when recent surface landslides occurred (Fig. 3). There are boulders of limestone in the lower part of the rotational surface of rupture corresponding mostly to the 1714 landslide, and secondary boulders to later ruptures, but did not progress too far downward that was dragged by the tongue of the landslide. This area is very humid with springs and the water that tends to puddle.

The area of deflation gives way to the tongue area where a raised relief predominates due to the irregular bulging of the mass as a whole (Fig. 2 and photographs in Fig. 3). Unlike the adjacent thalwegs, here the topographic contour lines are slightly convex down the slope. In this part, there are many lobes and steps that vary with time, which are the result of differential movements within the earthflow.

The thalweg through which the clayey mass flowed corresponds like the rest of the thalwegs of the other streams that descend from Las Malloas, to a Pleistocene-Holocene relief, and erosion predominates in all of them, they also lack alluvial deposits. In the Ycibar stream below Inza and below the mass of the landslide, alluvial deposits were not evidenced in the boreholes, although a more weathered layer was found.

\subsection{Hydrogeology}

\subsubsection{The springs that drain the karstic aquifers of Las Malloas (Inza)}

From the hydrogeological perspective, the northern edge of a large karstic system drains in a general way toward the Iribas spring, with an average flow of about $1500 \mathrm{~L} / \mathrm{s}$. However, in this peripheral area, there are local flows associated with the headwaters of the ravines. Although it is not only the topography that conditions the flow, the separation of the limestone by semi-permeable levels, the network of fractures that affect them, and their 
(A)
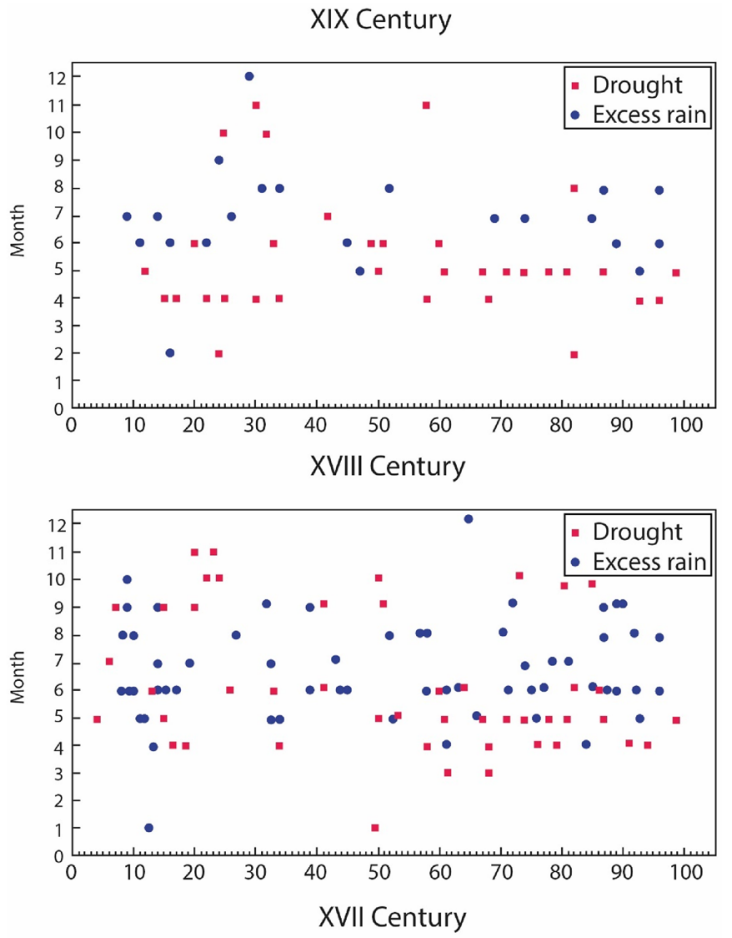

(B)

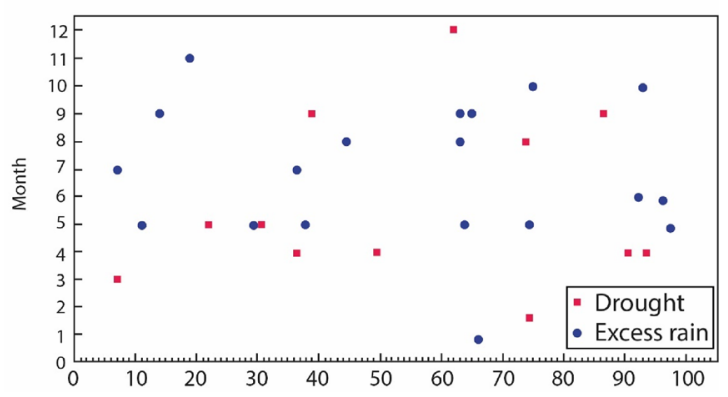

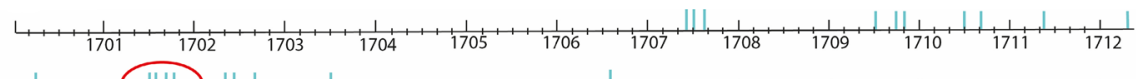

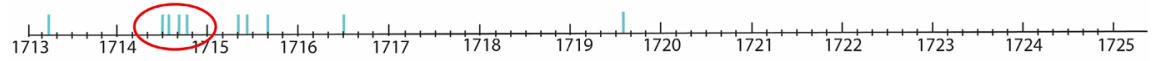

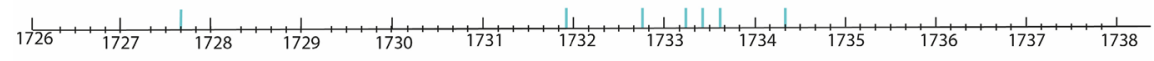

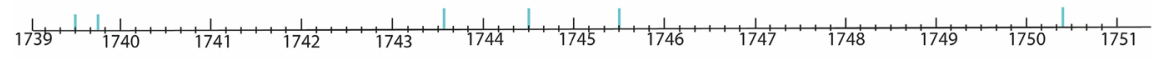

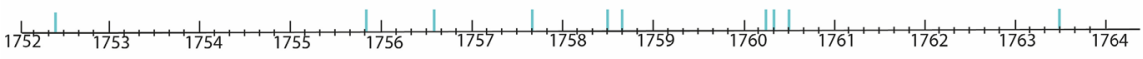

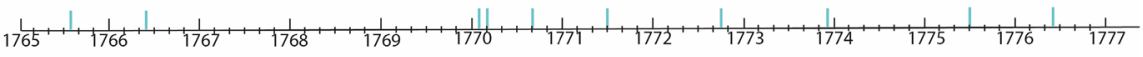

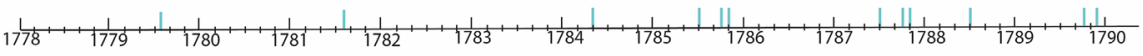

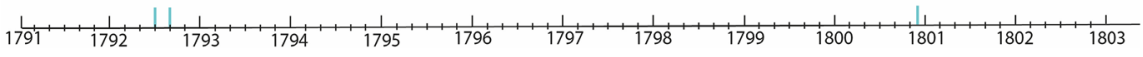


Table 1 Dimensions of the landslide of Inza according to terminology by Dikau et al. (1996)

\begin{tabular}{llrl}
\hline Notation & Dimensions & $(\mathrm{m})$ & Measurement type \\
\hline$W_{\mathrm{d}}$ & Width of the displaced mass & 350 & Direct (field) \\
$L_{\mathrm{d}}$ & Length of the displaced mass & 1400 & Direct (field) \\
$D_{\mathrm{d}}$ & Maximum depth of the displaced mass & 180 & Deduced (field profile) \\
$H_{\mathrm{d}}$ & Height of the displaced mass & 450 & Deduced (field profile) \\
$W_{\mathrm{r}}$ & Width of the failure surface & 350 & Numerical model (Fig. 9) \\
$L_{\mathrm{r}}$ & Length of the failure surface & 650 & Numerical model (Fig. 9) \\
$D_{\mathrm{r}}$ & Depth of the failure surface & 160 & Numerical model (Fig. 9) \\
$H_{\mathrm{r}}$ & Height of the failure surface & 325 & Numerical model (Fig. 9) \\
$L$ & Total length of the landslide & 1450 & Numerical model (Fig. 10) \\
\hline
\end{tabular}

opening near those cut by mechanical decompression, can give rise to small compartmentalized aquifers with more or less independent hydraulic operation. These are small karstic systems with a reduced feeding area, limited to the edge of the cut. Some of the chasms on this upper edge, such as the Elekomuts North, keep the winter snow inside, which then melts in summer. The underground water flow of this chasm seems to be directed through fractures toward one of the springs located at the base of the cliffs of Las Malloas (Galán et al. 2019). There is also information from an accidental test from 1942 with a tracer of cloudy water infiltrated in the upper part of Las Malloas, $1.5 \mathrm{~km}$ away from the Inza spring, and with the groundwater sink at $1180 \mathrm{~m}$ altitude. The cloudy water emerged at the source of the Inza stream, confirming the relatively greater extension of the recharge area of this spring (Eloségui 1976).

At the base of the lower walls and flanks of Las Malloas in each of these thalwegs, there are numerous small water emergences, many of them temporary. Some are hidden by the block fillings and colluvial material that cover the lower flanks. More than twenty small springs were located during the autumn 2018 from the base of the walls of Irumugarrieta peak $(1430 \mathrm{~m})$ in Gainza, up to $2 \mathrm{~km}$ further east, up to the foot of the cliffs of Las Malloas de Inza (Galán et al. 2019). Water emerges at the points of least relative height from the contact of different limestone-slate permeability, and in the direction of fracture systems. There are no continuous data on the gauges of these springs, but from what was observed by Galán et al. (2019) and those who carried out specifically in this research on different dates, the water flow can reach a total of $50 \mathrm{~L} / \mathrm{s}$ of average annual flow.

The concentration of several of these water emergences associated with a NW-SE fault near the head of the Inza landslide (Fig. 2) is very significant, as well as the presence of water emergence of about $4 \mathrm{~L} / \mathrm{s}$ in the limestone-slate contact within the area of the rotational surface of rupture. It is known that these upwellings have a very variable regime, typical of developed karst, being able to reach appreciable flows after heavy rainfall and thaw.

\subsubsection{Hydrogeology in the slip body and in the slatey substrate}

Figure 2 shows the situation of the springs in the area surrounding the landslide. Apart from the relatively more abundant springs located in the limestone-slate contact, it is worth noting the abundance of springs spread out over all the slopes. In general, these are permanent springs with a small flow, usually less than $1 \mathrm{~L} / \mathrm{s}$, but they satisfy the 
domestic needs of villages, or contribute to the ecological flow of the streams. Rainfall is so high that although siltstones and slates are not very permeable, they have been permanently recharged, and the weathered upper layers have a high water table close to the surface.

As mentioned above, a permanent stream of water originates at the head of the landslide from a spring that drains the karstified limestones of Las Malloas, although the outbreak is masked by debris and slide mass. As we shall see, this water emergence was the main cause of this slope movement. The phreatic level is in any case very high in the lower zone of the rotational surface of rupture where it emerges in the form of ponds. This area keeps the moisture in the head of the sliding tongue as the water is transferred underground. To reduce the movement and activity of the tongue, a transversal drainage ditch was made in 1985 to cut and capture this water flow. Within the tongue of the landslide, and according to data (DOPGN 1999, 2000) from the four piezometers and several water points of manual wells of 1.5-2 $\mathrm{m}$ depth, ditches, springs and streams, located there, the water table is also very close to the surface (Fig. 6b), sometimes appearing after the rains in the form of temporary springs. The oscillation of the phreatic level does not exceed one meter between dry and wet years: It can be said that the mass of the tongue is mostly saturated with water, since the material that forms it is not very permeable and drains with difficulty.

\subsection{Landslide activity and movement after 1714}

\subsubsection{In the area of the main scarp at the head}

Along the foot of all the cuts in Las Malloas, there are large detached rocks and colluvial material in general. Sometimes reactivations can be observed in them, which are shown by scars from take-offs in blocks and solifluction steps on the slope.

Regarding the Inza valley and landslide, and according to the serial sequence of ten aerial photographs that have been available since 1929 to the present (1929-1945-19 56-1973-1984-1998-2005-2010-2014-2019) (IGN), it is observed that, in the area of the main spoon-shaped head scarp originating from the main event of 1714, there were at least six episodes of minor and superficial landslides over the last century, which indicate that this area is still somewhat unstable. They coincide with rainy episodes and the reactivation of tongue movement. These instabilities lead to the temporary removal of the scrub and forest vegetation, which grows back very quickly. One of these reactivations corresponds to that of 1984, coinciding with rains and an appreciable movement of the tongue (Aparicio et al. 1987). For the most part, these minor landslides are limited to the interior of the zone of rotational surface or rupture, but there are also landslides outside, bordering it in all directions, which indicates the existence of stresses behind the main failure in 1714. Figure 6a shows the schematic and chronological maps of these instabilities.

However, the aerial photographs do not reflect all the activity at the head of the landslide, since there were reports of other important landslides, such as the one in April 1966 when a huge $6000-\mathrm{m}^{3}$ rock from Las Malloas rolled down causing alarm in the hamlets of the area (Eloségui 1976). In the years prior to this landslide, small displacements from this sector of the cliff had already been observed. In 1999, there was another report of a smaller landslide. 


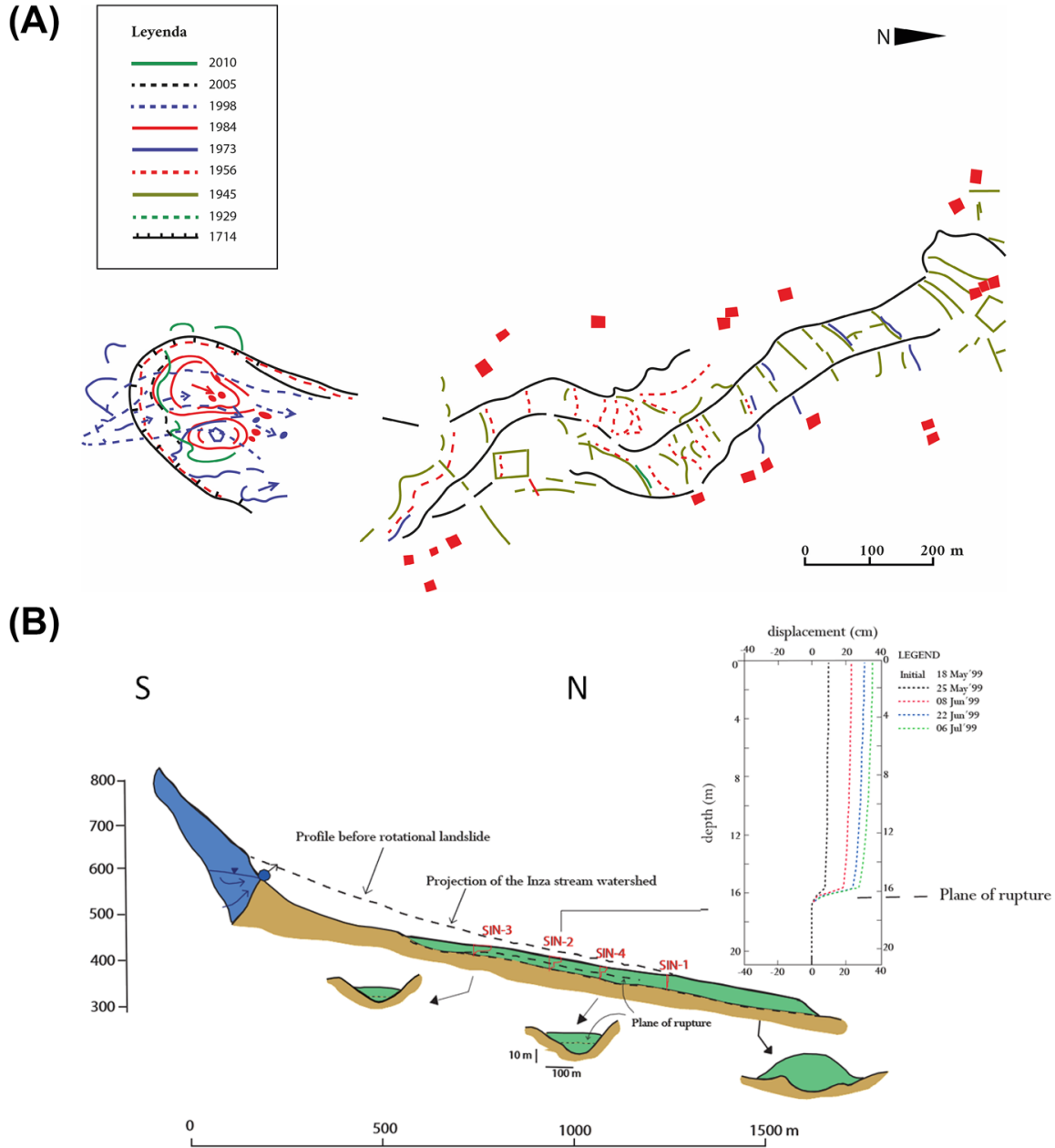

Fig. 6 a Sequence of recent movements with minor surface landslides but appreciable in the head area and variations in the boundaries according to a frame record from 1929. b Axial section S-N of the slide with inclinometer profiles indicating failure planes. The zero measurement of inclinometers was 18/5/1999 for SIN-1, 25/5/1999 for SIN-2 and 6/7/1999 for SIN-3

\subsubsection{In the earthflow: variable speed movement according to the rain and with the distance to the head}

A sequence of aerial photographs from 1945-1956-1973-1998-2005-2010-2014 were made available from which we made the following observations (Fig. 6a): Taking the boundaries of the meadows and ground plots, as well as roads and paths relative to fixed references outside the landslide, such as the hamlets, for example, saw small downward movements. The maximum observed were at the start of the tongue with an average of $2 \mathrm{~m} /$ year from the forties-fifties till the end of the twentieth century. These movements progressively reduced in the lower areas of the valley with speeds of no more than $1 \mathrm{~m} /$ 

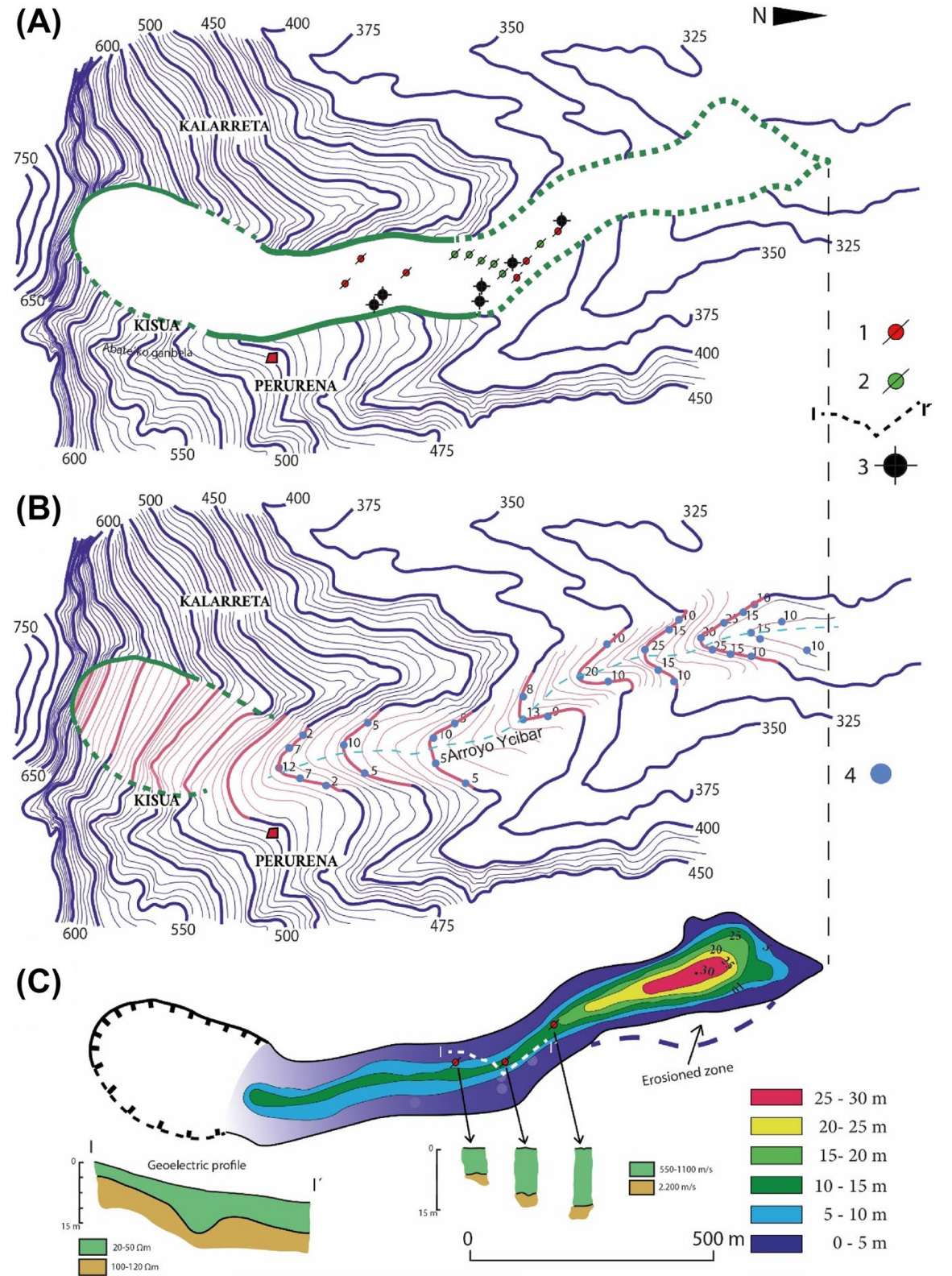

Fig. 7 Phases of reconstruction of the topography prior to the Inza landslide: a Detail of the topography on both sides of the slopes of the head scarp and location of boreholes and geophysical prospecting to determine the depth of the substrate under the tongue. The area affected by the landslide, whose topography has to be reconstructed, is blank. Situation of the seismic refraction surveys (1), geoelectrical profile I-I' (2) and boreholes (3) in order to know the height of the thalweg floor (4 in B) and the thickness of the sedimentation area. b Extrapolation of the topographic contour lines in the header area taking into consideration the adjustment in which the volume of mass moved by the landslide. In red, contour lines of the reconstructed topography. c Total thickness of the sliding mass (in m). Simplified geoelectrical profile I- $\mathrm{I}^{\prime}$ and seismic refraction surveys indicating the depth of the substrate according to the resistivity of the ground and the velocity of the seismic waves (Adapted from IGME 1985) 
year in the intermediate zone and imperceptible in the lower zone, where even three hamlets have been built within the landslide.

These observations made with aerial photography were confirmed in the field with the testimony of the inhabitants. Since the landslide, the local people have always noticed a slow movement, at least up to the Orexanea hamlet (Fig. 2). They have noticed that after a rainy season the flow advances with greater speed and, if after a dry season it begins to rain, the movement occurs with certain delay after a few days. The movement is greater in the upper part of the tongue and negligible in the distal part, in such a way that since 1944 three new houses on the lower part of the sliding tongue were even built (Fig. 2).

In the middle part, there are lobes and convex morphologies that vary over time, so that the boundaries and fences of the farms and meadows were displaced and their surface modified. These variations are small but noticeable in the cadaster, so that some meadows have gained ground by elevation of the ground to the detriment of the neighbors. Cracks and waterlogged areas were also formed in the small depressions.

\subsubsection{Inclinometers}

Three inclinometers were installed along the axis of the tongue of the sliding filled mass (Figs. 2 and 4) up to the height of the Orexanéa hamlet. One is located in the upper zone, another in the intermediate zone, and another in the lower zone. They were installed in boreholes drilled with rotary percussion with depths between 20.2 and $40.3 \mathrm{~m}$. The readings were taken over the course of a year (1999-2000). Inclinometer (1) had a movement of $38 \mathrm{~mm}$ from the surface to the plane of failure located at $16.5 \mathrm{~m}$. It had a seasonal movement according to rainfall with a speed of $23.3 \mathrm{~mm} / \mathrm{month}$. Inclinometer (2) had a movement of $24 \mathrm{~mm}$ from surface to plane of failure located at $18.5 \mathrm{~m}$, with a seasonal movement according to rains with speed of $51.4 \mathrm{~mm} / \mathrm{month}$. Inclinometer (3) showed two failure planes, one at $15.5 \mathrm{~m}$ and the other at $32 \mathrm{~m}$, with a movement of $42 \mathrm{~mm}$ from the surface to the first failure plane and a constant movement of $13 \mathrm{~mm}$ to the other failure plane. Velocities of $5.76 \mathrm{~mm} / \mathrm{month}$ on the surface, $5.33 \mathrm{~mm}$ at $14 \mathrm{~m}$ depth and $1.8 \mathrm{~mm}$ at $30 \mathrm{~m}$ depth were obtained.

\subsection{Reconstruction of the pre-slide topography}

Retrospective analysis of a landslide through mathematical modeling requires knowledge of the topography prior to the landslide. This is a characteristic difficulty of historical landslides like the one in Inza, since the topographic maps of 1714 are now missing. Although attempts were made to find such maps, there are no drawings of the Inza landscape or any graphic representation of the Sierra de Aralar and Las Malloas. However, and in spite of having a certain amount of subjectivism, based on geomorphological criteria of the environment and information on the geometry of the landslide, this aspect can be approached with an acceptable guarantee.

At the head of the landslide, which is where the rotational landslide occurred, the steps we followed were:

1. The breakage of the landslide mostly affected the slate. The slopes carved in the slate around the top hole are here fairly regular, with a steady slope (see topography in Fig. 7a for the Kalarreta and Kisua locations). So the topography of the rotational hole of the surface of rupture was reconstructed here by extrapolating the contour lines of the slopes 
on both sides of the landslide head scarp. The hole is somewhat asymmetrical, since this scarp has a horseshoe shape that extends a little further on the western side than on the eastern side. The end of the edge of the horseshoe on the west side has a very welldefined topographic expression. On the eastern side, the limit of the breakage hole near the hamlet of Perurena is well marked (Fig. 7a), toward the height of $475 \mathrm{~m}$, where the ground rose and closed the thalweg that comes from Abate'ko Ganbela. This formed an elongated lagoon that still exists today in the form of a pond, with the earthen dam hanging from the slope as if it were a lateral moraine dam. Further up, above the contour line $600 \mathrm{~m}$, the slope increases considerably, in line with that corresponding to the cliffs of Las Malloas and which are still preserved on the sides.

2. For this extrapolation, the volume of the sliding mass $\left(1.2 \mathrm{Mm}^{3}\right)$ was taken into account and calculated in step 4 below, prior to this adjustment. The filling of the void by the earth compensation coincides very well with the extrapolation of the topographic contours of the slopes that remain on both sides. The result is the continuation of a buttressed slope, where the source of the Ycibar stream is located at the lowest point of contact between limestone and slate, a spring with a flow rate capable of moving operating mills.

The following steps were taken to reconstruct the topography of the thalweg where the tongue slipped through:

3. From the data of the boreholes and geophysical surveys (Fig. 7a), it was relatively easy to reconstruct the topography of the thalweg hidden beneath the mass that, as can be seen, follows the general trend of the neighboring areas (Fig. 7b). It can be seen that the Ycibar thalweg extends upward through the thalweg of the Abate'ko Ganbela ravine, which has a larger watershed and greater erosive capacity than the source of the Ycibar stream.

4. The difference between this topography and the current one results in the thickness map of the sliding mass in Fig. 7c. Due to this thalweg, the flow could be redirected and this mass could be preserved inside it, since the erosion during and after the landslide is still considered small. The volume of soil and altered area that the tongue could have dragged from the bottom of the thalweg as a bulldozer can also be considered small. This volume was $1.5 \mathrm{Mm}^{3}$, which multiplied by a reduction coefficient of 0.8 (typical of embankments from cuttings), was used to compensate for the void above. The map in Fig. 7c also indicates the approximate limit between the deflation zone and the deposition zone within the landslide, i.e., the completion of the edges of the scarp in the shape of a horseshoe.

\subsection{Retrospective modeling}

\subsubsection{Geomechanical characterization of the clays of the base}

The contrast of stratigraphic units and difference of resistant characteristics where the original 1714 landslide took place can be clearly detected from the characteristics from the wave velocity data obtained in the available geophysical tests (Aparicio et al. 1987). In Table 2, are shown the seismic wave velocities obtained at different depths for the seismic refraction profiles. The slatey substrate corresponds to a wave speed of $2200 \mathrm{~m} / \mathrm{s}$, which, according to local geological knowledge of the area, corresponds to a healthy slatey mass 
Table 2 Seismic wave velocity of the different lithologies (Aparicio et al. 1987)
Stratigraphic unit

Seismic wave velocity $(\mathrm{m} / \mathrm{s})$

Slide mass 550

Weathered Slates

1100

Slatey rocky substrate

that can be assigned average values proposed by Serrano (1997), as indicated in Table 4. The values of the cohesion and angle of friction have a range of variation so that their combination allows an adequate stability back-analysis in the numerical calculation.

The slide mass is made up of a heterogeneous mass in which fragments of gravel-sized slate mixed with a clayey matrix predominate, although there are also limestone and some larger blocks of limestone. The granulometry of the samples corresponds to a percentage of fines between 20 and 60\%. According to the Unified Soil Classification System (USCS), the plasticity chart was used to classify the samples. Considering that samples were obtained at different depths (between 2 and $20 \mathrm{~m}$ ), the USCS results have several "points" on the plasticity chart (Fig. 8), mainly in all cases being low-plasticity silty clays (CL) or low-plasticity clayey silts (ML). The results of the geotechnical tests on unaltered samples of the slide mass indicated in Sect. 2.5 are summarized in Table 3. It is worth noting that the direct shear test was performed on an undisturbed sample located at a depth of $5 \mathrm{~m}$, resulting initially in a peak resistance value and finally in a residual value from a deformation threshold. Given the large deformations expected in the sliding mass, the residual value of the angle of friction was adopted. The sample tested in direct shear to characterize the resistant parameters was obtained from the body of the slide mass (in boreholes indicated in Fig. 7a) considering: (a) a sufficient depth to avoid surface alteration; (b) a distance sufficiently far from the failure surface, where the plastic breakage has produced

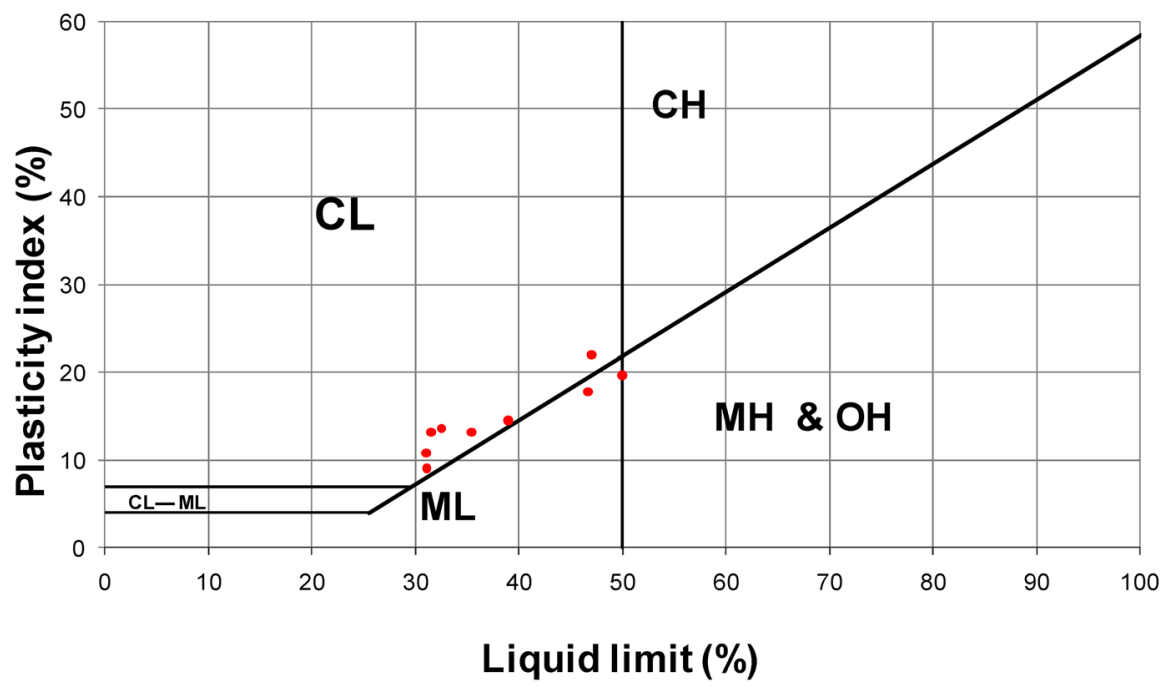

Fig. 8 Tested samples on the plasticity chart. $\mathrm{C}=$ clay; $\mathrm{H}=$ high; $\mathrm{L}=$ low; $\mathrm{M}=$ silt; $\mathrm{O}=$ organic 


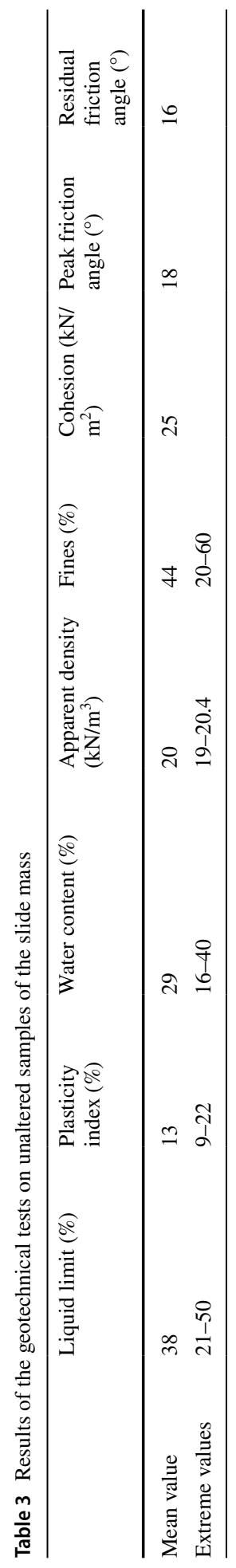


Table 4 Geomechanical parameters of the different lithologies used in numerical modeling

\begin{tabular}{llll}
\hline Stratigraphic unit & $\begin{array}{l}\text { Apparent } \\
\text { density } \gamma \\
\left(\mathrm{kN} / \mathrm{m}^{3}\right)\end{array}$ & $\begin{array}{l}\text { Effective } \\
\text { cohesion c } \\
\left(\mathrm{kN} / \mathrm{m}^{2}\right)\end{array}$ & $\begin{array}{l}\text { Effective } \\
\text { friction angle } \\
\varphi\left({ }^{\circ}\right)\end{array}$ \\
\hline Slide mass & 20 & 25 & 16 \\
Slatey rocky substrate & 26 & $120-200$ & $34-40$ \\
\hline
\end{tabular}

large deformations that have modified the constitutive behavior of the material, causing a remolded material. In this way, a depth of $5 \mathrm{~m}$ makes it possible to guarantee the above conditions and a singular behavior of the mobilized mass is not expected since this depth represents an intermediate point of the thickness of the sliding mass due to the earthflow over the Araiz Valley. Therefore, the obtained resistance values are considered acceptable, although with limitations, since it should be noted that the mobilized mass may have undergone subsequent displacements in different phases and depths that may have altered the results obtained in the laboratory. Finally, the geotechnical characteristics considered for numerical modeling are indicated in Table 4.

\subsubsection{Numerical simulation}

The numerical simulation was performed using two 3D models with the FLAC 3D geotechnical software:

- The first model simulates the original landslide of 1714 that occurred in the head scarp.

- The second model represents the earthflow over the Araiz Valley derived from the original sliding mass.

All materials were modeled with a Mohr-Coulomb failure criterion, with parameters assigned according to Table 4 shown in the previous section.

For the boundary conditions, horizontal constraints for lateral contours and both horizontal and vertical constraints for the lower boundary of the model were considered. First of all, initial stresses under static conditions (only under vertical gravity loading) were calculated, considering the water pressure caused by the water table at the head of the slope. The estimation of horizontal effective stresses was performed with Jaky's formula because, even though this was not a horizontal layered soil configuration, it was considered accurate enough for this estimation.

From the recreated pre-failure topography, Fig. 9 shows the 3D failure surface obtained for the numerical model of the original landslide of 1714 that occurred in the head scarp. Retrospective analysis of the stability made it possible to obtain strict equilibrium for cohesion values of $150 \mathrm{kPa}$ and friction angle of $38^{\circ}$, where the high displacement values indicate that the failure occurred and that the landslide was generated. As can be seen from the stability calculation, a rotational failure surface with a very close to the unit safety coefficient that indicates the strict balance of the mass considered in this calculation was obtained. In Fig. 9b is shown the contour of the breaking surface, including the direction of the slip and the exit from the foot is marked, which clearly denotes the rotational character of the landslide.

The model in Fig. 9b can be seen that the foot of the landslide was approximately $650 \mathrm{~m}$ from the main scarp, completing the information in Sect. 4.2 where it was indicated that the visible part of this slide was about $350 \mathrm{~m}$. 
(A)

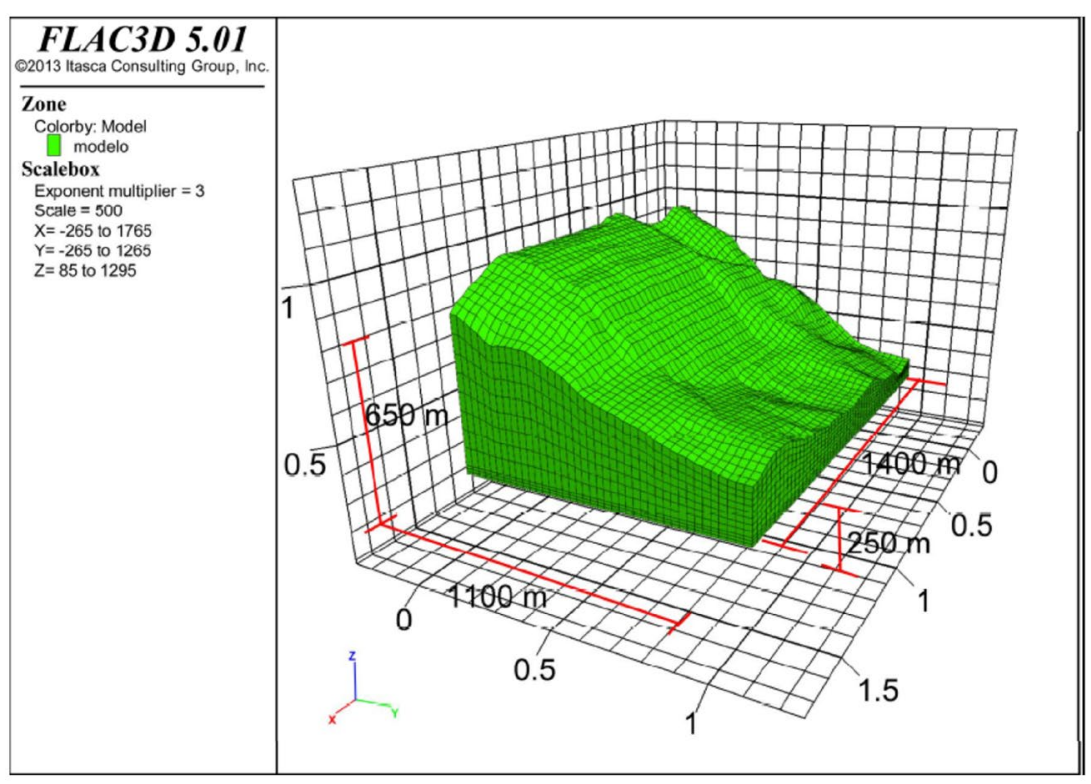

(B)

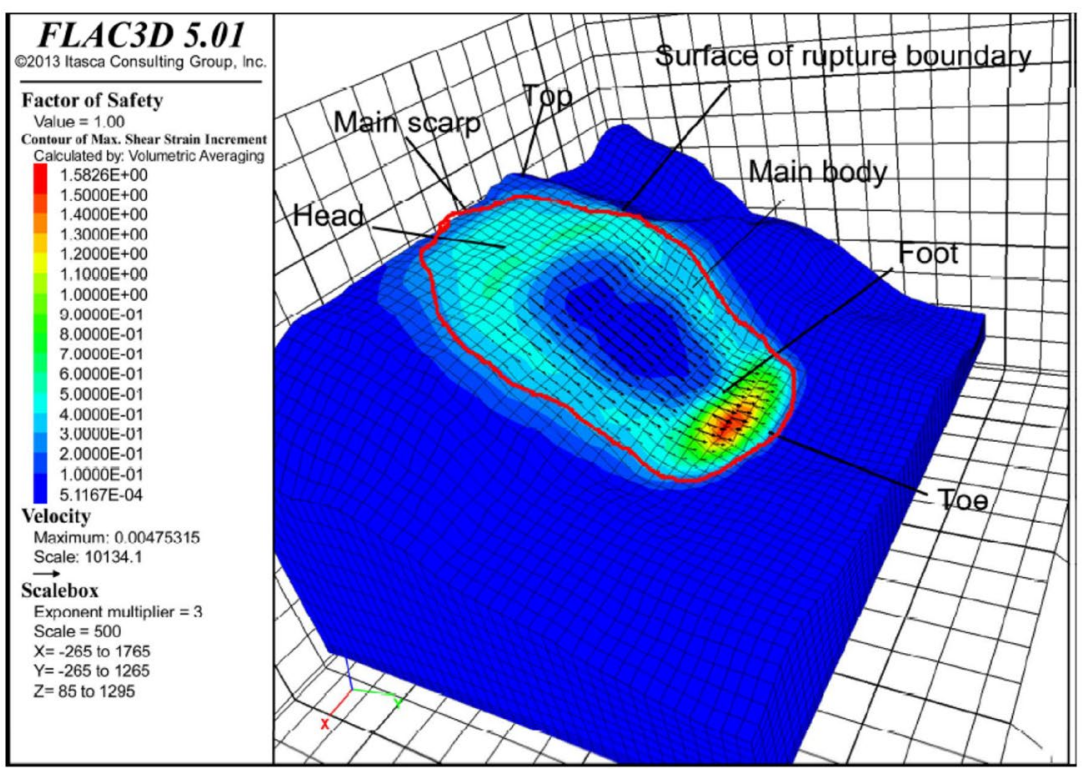

Fig. 9 Numerical simulation of the original landslide of 1714: a recreated pre-failure topography; b rotational surface of rupture

The numerical validation includes the initial equilibrium of stresses and water flow under stable conditions and obtaining negligible stresses in the lateral contours of the calculation model with a failure mode compatible with geological observations.

In the same way, the model of stability of the slide mass over the Araiz valley was carried out. Figure 10 shows the numerical model based on the geometry obtained with the 


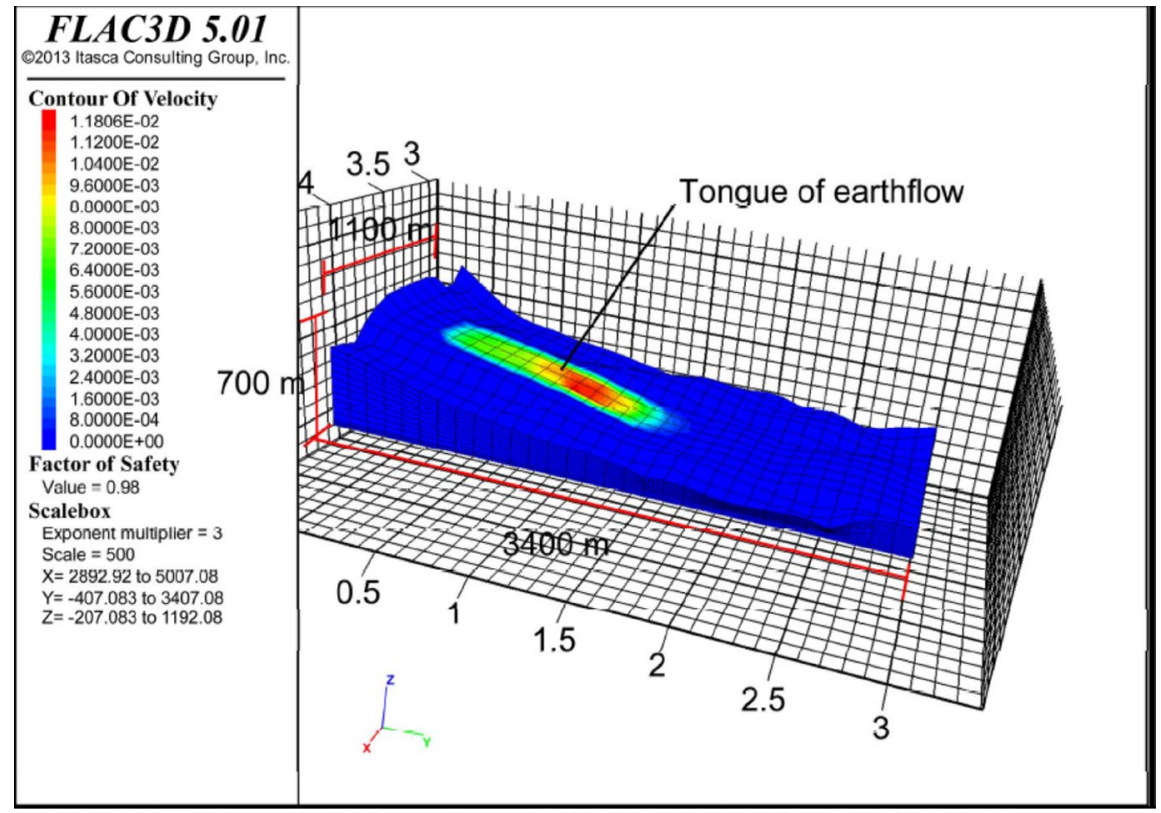

Fig. 10 Numerical simulation of the earthflow over the Araiz Valley derived from the original sliding mass

current topographic lines and the water level at the head, obtaining, for the parameters indicated in Table 4, a global safety coefficient close to strict equilibrium. Therefore, it can be concluded that the seasonal conditions of water fluctuation are potentially unstable for the slide mass for the original 1714 landslide located in the Araiz Valley, thus generating an earthflow.

\section{Discussion}

\subsection{Origin of the landslide of 1714-1715: a very humid period within the Little Ice Age}

Historical research shows that no major landslides occurred in the village for at least 500 years. This statement could apply further back in time, as there is no geological or geomorphological evidence to suggest that there were other important mass movements in this area during the recent epoch. The configuration of the relief and the thalwegs that descend from the mountains is at least from the Upper Pleistocene, and the absence of deposits from previous landslides in the Inza valley and adjacent valleys seems to indicate that the 1714-1715 landslide is the only important event of this type that occurred recently.

Without doubt, the origin of the landslide is related to the special location at the most important discharge point of the local flows of the limestone aquifer of the Sierra de Aralar at its northern edge, in the area of Las Malloas. However, according to the topographical reconstruction prior to the landslide, instead of a pronounced thalweg, the slates formed a buttress or wall that covered the karstified limestones of the Urgonian as an impermeable 
barrier, with the spring probably hanging halfway up the slope. This spring is almost certainly related to a NW-SE fault, exactly the same as another parallel one located further west and which is also drained by a group of springs located very high, at $650 \mathrm{~m}$, exactly at the same level as the upper edge of the landslide scarp (Fig. 2). This hydrogeological situation of the location of springs in the limestone-slate contacts is repeated in the adjacent thalwegs, but almost always at the bottom of the thalwegs. Only in the annexed western thalweg are there slate buttresses. None have a greater discharge than in the Inza valley, and none of them have caused recent landslides of this magnitude that are known.

However, the triggering cause was due to the exceptional conditions of recharge and discharge of the aquifer in quantity and duration that occurred in the second half of 1714, probably the wettest year of the fifteenth, sixteenth and seventeenth centuries, and within a humid lustrum situated in the middle of the Little Ice Age. The year 1714 was included in a humid lustrum and in the middle of the Little Ice Age, when not only did it rain more, but the lower temperatures would have contributed to the greater recharge of the aquifers, partly due to less evaporation in summer, and greater snowfalls. As mentioned already, in some of the existing chasms in this aquifer, such as the Elekomuts North, the snow directly enters, accumulates and preserved inside as an icebox, which then melts in summer.

The particular hydrogeological context of the source of the Ycibar stream created the general instability of the slope: the extraordinary contribution of underground water, concentrated toward one or multiple springs hanging in the middle of the slope, was decisive for the water to be transferred to the slatey marls at the base and colluvial material attached to the foot of the cliffs, or simply moisten them from above by means of various streams from the limestone-slate contact. Subterranean transfer of limestones to slates near the thrust fault is possible as these slates are fractured at this mechanical contact. Materials with low permeability (e.g., siltstones, clays and slates), the rainfall during the previous summer months and the pre-saturation affected the conditions for the preparation of the landslide. The melted snow that form at the foot of Las Malloas during this wet winter must also be considered. All this would have caused the sharp increase in the pore pressures and the destabilization of the whole mountain side, triggering a new deep breakage. In the generation of such a failure, the presence of the NW-SE fault as a weakness plane and conductive of water would surely help. The spoon-shaped breakage mobilized a 1.2$\mathrm{Mm}^{3}$ mass of slatey marls and large limestone boulders that formed a lobe. The depression between the main scarp and the crest of the lobe was gradually filled with water in the form of a lagoon from the springs that were born immediately upstream. This lobe also closed a lateral thalweg, forming another hanging lagoon, which still exists as a pond.

\subsection{Current residual activity and reactivations}

After this event, the landslide remained dormant, although with a constant residual activity and in permanent movement, experiencing accelerations after periods of rain. After it rains, the tongue of the landslide follows its movement superficially on the edges of meadows and farms.

The speed of the earthflow conforms to the measurements of the inclinometers and the variation observed in the meadow boundaries according to aerial photographs. In more than the upper half of the earthflow, which is inside the valley box, and in which there is a perceptible movement, two planes of breakage appear. One is between 15 and $18 \mathrm{~m}$ deep, where there is only one movement from the surface to the plane of breakage and where the movement is much greater. There is another deeper breakage located at the bottom of the 
valley, above which the movement is much less. This occurs because the friction with the substrate at the bottom of the valley cancels out the movement at the bottom of the mass, forcing it to break within that lower zone at a depth where that internal friction is overcome. Thus, there is a superficial zone that takes off inside it and where the central part advances faster. This sliding surface is geomechanically the worst feature and corresponds to the critical breakage, resulting numerically (Fig. 10) when it occurs in the interior of the mass, continuously, and not dependent on the friction surface with the bottom of the valley.

The movement decreases downward, as can also be seen in the aerial photographs, so that it is imperceptible in the lower third. According to Cruden and Varnes (1996), this movement is currently classified as very slow at the top. In order to reduce the movement and activity of the tongue, a transversal drainage ditch was made to cut and capture this water flow.

\subsection{Wet periods and large landslide activity}

First of all, a distinction must be made between new generation breakages and reactivation of existing landslides. Exceptional rainfall episodes are not always a necessary condition for breakage. On the contrary, rain is the most frequent cause of the reactivation of latent landslides and the acceleration of already active ones (Corominas 2006). Many early breakages are more the result of a long-term evolutionary process of the slope than the response to a particular trigger. The analysis of the behavior of large landslides needs to take other factors into account, and in this context it was possible to gain sufficient knowledge of the particular hydrogeological events at Inza. This event gave rise to a new generation of breakages, although associated with a long-term wet period. It is therefore not surprising that one of the main periods of landslide activity in the past took place during the Little Ice Age (Grove 1972). Inza is not a unique case in this area; the arrangement of highly permeable materials on impermeable surfaces is repeated in a large part of the mountain ranges that make up the Basque-Cantabrian basin, where there are also records of large landslides from a massive detachment, for example: Ormaetxea et al. (2013, 2017). In a review of 20 large landslides distributed throughout Spain, Ferrer and Ayala (1997) observed that the breakages and reactivation of landslides and debris flows occurred in abnormally high rainfall episodes, with values ranging from 15 to $120 \%$ of the average annual rainfall.

The relationship between rainfall and the reactivation of large landslides and the generation of smaller landslides is clearer. In the northern region of Spain, several authors have found an increase in the instability of the slopes of the Valle del Pas in Santander related to historical humid climatic phases (González-Díez et al. 1996; Valenzuela et al. 2018), especially in the sixteenth-eighteenth centuries. This is a phase when shipyard activity also implied an important felling of forests in the region. And finally the nineteenth century also coincided with the end of the Little Ice Age and an increase in precipitation and greater human activity. Several of these phases have also been observed in the Pyrenees (Moya et al. 1997). In the last century, the most important episodes of slope instability in the Catalan Coastal Range, Eastern Pyrenees and Iberian range mainly happened in autumn-October and November-although sporadically there were some episodes during other seasons. In the Cantabrian range, the Betic range and the great Neogene depressions of the Iberian peninsula, the breakages are more frequent in winter and spring (Corominas et al. 2017).

Regarding Inza, the head area is still somewhat unstable during the rainy season, producing minor landslides that modify the slope of the main scarp from 1714. But there is also a tendency on the edge of the periphery that is indicative of tractions that tend to go up 
the main breakage. Most of its surface is continuously vegetated, except at the head, where from time to time minor superficial landslides occur on the main scarp which temporarily remove any trees and bushes. The chronology of these small instabilities, summarized in Fig. 6a, seems to coincide with one of the wet periods recorded in this northern area of Spain. In fact, the relationship between wet periods and landslide frequency was verified in the twentieth century, where two wet periods of great activity were detected, those of 1905-1930 and 1958-1987, and a period of relative tranquility that spans from the 1930s to the 1950s. This apparent cyclicality has also been observed in other European regions, although not at the same time periods (Ormaetxea et al. 2017).

The moderate reactivation of the tongue in the Inza landslide after significant rainfall is a phenomenon that has also been observed in relatively nearby regions, such as the rotational and translational landslides in the Eastern Pyrenees. Usually reactivation happens during episodes of moderate rainfall intensity, between 40 and $100 \mathrm{~mm}$ of rain in $24 \mathrm{~h}$, provided that $90 \mathrm{~mm}$ or more of rain has accumulated in the preceding days (Corominas and Moya 1999). In Inza, this amount of rain is enough for the water table to rise one meter after it rains to notice a slow reactivation of the earthflow, as seen in March 1999 (DOPGN 1999, 2000).

Regarding future activity due to the consequences of climate change, it seems that the circulation models for the different scenarios of $\mathrm{CO}_{2}$ emissions forecast an increase in the intensity of precipitation in many parts of the world. Especially in areas of western winds exposed to precipitation of orographic origin and this is the case of the Cantabrian side of the País Vasco and the north of Navarra, such as the Sierra de Aralar.

\section{Conclusions}

As a result of the interdisciplinary methods that include historical documentation, geological, geomorphological and hydrogeological surveys, aerial photographs, geophysical prospecting, inclinometers and numerical simulation, it has been possible to understand the causes of this historical landslide and to reconstruct its evolution during the weeks that followed.

The landslide at Inza (Navarra, Spain) is a historical event that occurred in December 1714 after an exceptionally humid period during the Little Ice Age and associated with an area of underground water discharge that mainly affected the slatey marls and secondarily the overlying limestones. It is classified as a rotational landslide with a spoonshaped breaking surface. Due to the type of soil and the high water content of the foot lobe deposit, after 20 days the landslide generated a flow of clay and soil. This earthflow was channeled through the valley covering a distance of $1400 \mathrm{~m}$ to the village of Inza, destroying the church and 36 houses, without causing any casualties. This flow invaded the valley and almost filled it, with an average thicknesses of $20 \mathrm{~m}$, moving with an average speed of between 20 and $40 \mathrm{~m} /$ day. The landslide expanded at the intersection with two other valleys, where it accumulated a thickness of ground of more than $30 \mathrm{~m}$.

After the event, this landslide presents a residual activity that is reflected in the first place in minor landslides of retouching and setback of the head area. And secondly, in a small movement of the upper half of the earthflow of no more than $50 \mathrm{~mm} / \mathrm{month}$ in spite of the rain, which is not noticeable on the distal zone. This movement is constant in depth until the main breakage surface located about 15-18 $\mathrm{m}$ from the surface. From there, and to the bottom of the old valley, the movement is negligible due to friction. 
Acknowledgements This work is part of the Projects GI1504350086 and GI1704350117 of the Research Group of Geology Applied to Civil Engineering of the Universidad Politécnica de Madrid. It is also partially funded by the project "Advanced modeling of hillside landslides (BIA2016-76253-P)" of the Ministry of Education and Science. We would like to sincerely thank Jose Maria Bernardo León Zudaire, of the General Management of Public Works of the Government of Navarra, for providing us with documentation regarding inclinometers.

Funding This work is part of the Projects GI1504350086 and GI1704350117 of the Research Group of Geology Applied to Civil Engineering of the Universidad Politécnica de Madrid. It is also partially funded by the project "Advanced modeling of hillside landslides (BIA2016-76253-P)" of the Ministry of Education and Science. Open Access funding provided thanks to the CRUE-CSIC agreement with Springer Nature.

Data availability Not applicable.

Code availability Not applicable.

\section{Declarations}

Conflict of interest The authors declare that they have no conflict of interest.

Open Access This article is licensed under a Creative Commons Attribution 4.0 International License, which permits use, sharing, adaptation, distribution and reproduction in any medium or format, as long as you give appropriate credit to the original author(s) and the source, provide a link to the Creative Commons licence, and indicate if changes were made. The images or other third party material in this article are included in the article's Creative Commons licence, unless indicated otherwise in a credit line to the material. If material is not included in the article's Creative Commons licence and your intended use is not permitted by statutory regulation or exceeds the permitted use, you will need to obtain permission directly from the copyright holder. To view a copy of this licence, visit http://creativecommons.org/licenses/by/4.0/.

\section{References}

Aparicio V, Ayala FJ, Sanz E (1987) Análisis del deslizamiento de Inza (Navarra) de 1714-1715. Boletín Geológico y Minero 98(3):112-122

Bièvre G, Jongmans D, Goutaland D, Pathier E, Zumbo V (2016) Geophysical characterization of the lithological control on the kinematic pattern in a large clayey landslide (Avignonet, French Alps). Landslides 13:423-436. https://doi.org/10.1007/s10346-015-0579-0

Borgatti L, Corsini A, Barbieri M, Sartini G, Truffelli G, Caputo G, Puglisi C (2006) Large reactivated landslides in weak rock masses: a case study from the Northern Apennines (Italy). Landslides 3:115-124. https://doi.org/10.1007/s10346-005-0033-9

Burda J, Veselý M, Řehoř M, Vilímek V (2018) Reconstruction of a large runout landslide in the Krušné hory Mts (Czech Republic). Landslides 15:423-437. https://doi.org/10.1007/s10346-017-0881-0

Cendrero A, Diaz de Terán JR, Farias P, Fernández-Menéndez S, González-Diez A, Jiménez M, Marquínez J, Menéndez-Duarte R, Salas L (1994) Temporal distribution and contribution of landslides to landscape evolution from Late Pleistocene to Present in the Cantabrian Cordillera, Spain. In: Casale R, Fantechi R, Flageollet JC (eds) Temporal occurrence and forecasting of landslides in the European Community. European Commission, Brussels, pp 425-506. https://doi.org/10.1016/0169-555X(95) 00076-H

Corominas J (2006) El clima y sus consecuencias sobre la actividad de los movimientos de ladera en España. Cuaternario y Geomorfología 20(3-4):89-113

Corominas J, Moya J (1999) Reconstructing recent landslide activity in relation to the rainfall in the Llobregat river basin, Eastern Pyrenees, Spain. Geomorphology 30:79-93. https://doi.org/10.1016/S0169$555 \mathrm{X}(99) 00046-\mathrm{X}$

Corominas J, Ayala F, Cendrero A, Chacón J, Díaz J, González A, Moya J, Vilaplana J (2005) Impactos sobre los riesgos naturales de origen climático. B. Riesgos de inestabilidad de laderas. In: Moreno JM (ed) Evaluación preliminar de los impactos en España por efecto del cambio climático. Ministerio de Medio Ambiente, Madrid, pp 549-579 
Corominas J, Mateos RM, Remondo J (2017) Review of landslide occurrence in Spain and its relation to climate. In: Book: Slope safety preparedness for impact of climate change (pp.351-377) Edition: 2017 Taylor \& Francis Group. London, UK. https://www.researchgate.net/publication/318109929

Cruden DM, Varnes DJ (1996) Landslide types and processes. In: Turner AK, Schuster RL (eds) Landslides. Investigation and mitigation. Transportation Research Board Special Report 247. National Academy Press. Washington, DC, pp 36-75. http://onlinepubs.trb.org/Onlinepubs/sr/sr247/sr247-003.pdf

Cruden D, Machel HG, Knox J, Goddard R (2014) The "Boscobel landslip" of October 1st, 1901 the largest historic landslide in Barbados, West Indies. Landslides 11:673-684. https://doi.org/10.1007/ s10346-013-0423-3

Díaz E, Sáenz de Olazagotia A, Ormaetxea O, Ibisate A (2012) Análisis de factores de desestabilización de laderas en dos cuencas del ámbito atlántico: Sollube-Mape (Bizkaia) y Ramaio (Alava). Cuaternario y Geomorfología 26(1-2):171-190

Dikau R, Brunsden D, Schrott L, Ibsen ML (1996) Landslide recognition. Identification, movement and causes. In: International Association of Geomorphologists, Publication 5. Wiley, Chichester

Domínguez MJ, Jiménez M, Rodríguez A (1999) Press archives as temporal records of landslides in the North of Spain: relationships between rainfall and instability slope events. Geomorphology 30(1999):125-132. https://doi.org/10.1016/S0169-555X(99)00049-5

DOPGN (Departamento de Obras Públicas del Gobierno de Navarra) (1999) Estudio estabilidad deslizamiento de Inza. Internal Report.

DOPGN (Departamento de Obras Públicas del Gobierno de Navarra) (2000) Conclusiones sobre el control mediante medidas inclinométricas en dos puntos singulares del deslizamiento de Intza, Navarra. TKL 201/13. TEKOLUR S.L. Internal Report.

Eloségui J (1976) El "terremoto" de Inza (1717-1715). Cuadernos de Etnología y Etnografía de Navarra 24:373-404

Esparza A (2002) Aproximación a la heráldica de las entidades locales de Navarra. Cuadernos de Etnología y Etnografía de Navarra 77:5-47

Ferrer M, Ayala FJ (1997) Relaciones entre desencadenamiento de movimientos y condiciones meteorológicas para algunos deslizamientos en España. IV Simposio Nacional sobre Taludes y Laderas Inestables. Granada. Vol. 1, 185197

Galán C, Herraiz I, Rivas JM (2019) Sima de Elekomuts norte (Sierra de Aralar): neveros subterráneos y detalles cartográficos- Laboratorio de Bioespeleología. Sociedad de Ciencias Aranzadi. https:// scholar.google.com/scholar?cluster $=2642615893388942223 \&$ hl=en\&as_sdt=0,5

Gallart F, Clotet N (1988) Some aspects of the geomorphic processes triggered by an extreme rainfall event: the November 1982 flood in the Eastern Pyrenees. Catena Supplement 13:79-95

GEN (Gran Enciclopedia de Navarra) (1999) Fundación Caja Navarra. https://www.fundacióncajanavarra.es

González-Díez A, Salas L, Díaz de Terán JR, Cendrero A (1996) Late Quaternary climate changes and mass movement frequency and magnitude in the Cantabrian region, Spain. Geomorphology 15:291-309. https://doi.org/10.1016/0169-555X(95)00076-H

Grove JM (1972) The incidence of landslides, avalanches and floods in Western Norway during the Little Ice Age. Artic Alpine Res 4:131-138. https://doi.org/10.1080/00040851.1972.12003633

Hutchinson JN, Bhandari RK (1971) Undrained loading, a fundamental mechanism of mudflows and other mass movements. Geotechnique 21:353-358. https://doi.org/10.1680/geot.1971.21.4.353

IGME (1985) Estudio geotécnico de cinco zonas inestables de Navarra. Deslizamiento de Inza. Internal Report

IGN (Instituto Geográfico Nacional) (1929,1945,1956,1973,1998, 2005, 2010, 2014, 2019) Fotografías aéreas a escala 1:33.000 y 1: 5.000. https://www.ign.es/web/ign/portal

Lomoschitz A, Meco J, Corominas J (2002) The Barranco de Tirajana basin, Gran Canaria (Spain). A major erosive landform caused by large landslides. Geomorphology 42:117-130. https://doi.org/10. 1016/S0169-555X(01)00078-2

Lopez-Sellés T (1974) Contribución a un catálogo de ermitas de Navarra (Merindad de Pamplona). Cuadernos de etnología y etnografía de Navarra, 301-358. https://dialnet.unirioja.es/servlet/artic ulo? codigo $=754750$

Lozano PL (2006) Régimen precipitacional en el norte de Navarra y Guipúzcoa: ¿record peninsular y europeo? Nimbus: Revista de climatología meteorología y paisaje 17-18:125-144

Mihalić S, Sečanj M, Bernat S, Krkač M, Begić H, Džindo A, Zekan S, Arbanas Z (2017) Landslides in the Dinarides and Pannonian Basin-from the largest historical and recent landslides in Croatia to catastrophic landslides caused by Cyclone Tamara (2014) in Bosnia and Herzegovina. Landslides 14:1861-1876. https://doi.org/10.1007/s10346-017-0880-1 
Moya J, Vilaplana JM, Corominas J (1997) Late Quaternary and historical landslides in the South-Eastern Pyrenees. Palaeoclim Res 19:55-73. https://doi.org/10.3166/ga.21.187-202

Köppen W (1936) Des Geograsphischen System der Klimate. Köeppen y R. Geiger: Handbuch der klimatologie, Borhtraeger. Berlin. http://koeppen-geiger.vu-wien.ac.at/pdf/Koppen_1936.pdf

Ormaetxea O, Sáenz A, Díaz E, Ibisate A (2013) A complex and multi-phase landslide: the study case of Andoin, Entzia range (Basque Country, Spain). In: 8th International Conference (AIG) on Geomorphology, p 650

Ormaetxea O, Barroso JC, Sáenz A (2017) Geomorphological characterization and analysis of rotational landslide evolution at Andoin, Sierra de Entzia (Basque Country). Cuaternario y Geomorfología 31(3-4):7-26. https://doi.org/10.17735/cyg.v31i3-4.55240

Sáez de Ocáriz M (1990) Climatología y régimen de lluvias en La Rioja Alta, siglos XVI al XIX. Zubia 8:129-178

Sanz E, Menéndez-Pidal I, Lomoschitz A, Galindo R (2016) The Pico de Navas slump (Burgos, Spain): a large rocky landslide caused by underlying clayey sand. J Iber Geol 42(1):55-68. https://doi.org/10. 5209/rev_JIGE.2016.v42.n1.49120

Serrano A (1997) Mecánica de rocas I y II. Publicaciones de la Escuela Técnica Superior de Ingenieros de Caminos, Canales y Puertos de Madrid. Madrid, Spain

Starkel L (1966) Post-glacial climate and the moulding of European relief. In: Proceedings of the international symposium on world climate 8000 to 0 B.C. Royal Meteorological Society, London, pp 15-32. https://doi.org/10.1002/qj.49709239319

Sturzenegger M, Stead D, Gosse J, Ward B, Froese C (2014) Reconstruction of the history of the Palliser Rockslide based on $36 \mathrm{Cl}$ terrestrial cosmogenic nuclide dating and debris volume estimations. Landslides 12:1097-1106. https://doi.org/10.1007/s10346-014-0527-4

Tarifa Castilla MJ (2008) Una nueva atribución al taller pictórico de los Oscáriz: el retablo mayor de Inza. Príncipe de Viana 69(244):271-310

Uriarte A (1996) El clima. Geografía de Euskal Herria. El clima y las aguas. Vol 3. Lasarte: Etor, pp 8-85

Valenzuela P, Domínguez-Cuesta MJ, Mora MA, Jiménez-Sánchez M (2018) Rainfall thresholds for the triggering of landslides considering previous soil moisture conditions (Asturias, NW Spain). Landslides 15:273-282. https://doi.org/10.1007/s10346-017-0878-8

Vassallo R, Grimaldi GM, Di Maio C (2015) Pore water pressures induced by historical rain series in a clayey landslide: 3D modeling. Landslides 12:731-744. https://doi.org/10.1007/s10346-014-0508-7

Zarroca I, Linares R, Roqué C, Rosell J (2014) Gutiérrez F (2014) Integrated geophysical and morphostratigraphic approach to investigate a coseismic translational slide responsible for the destruction of the Montclús village (Spanish Pyrenees). Landslides 11:655-671. https://doi.org/10.1007/ s10346-013-0427-z

Zubiri MO (1977) El corrimiento de tierras de Inza y su posible influencia en la mente de un vecino del lugar. Cuadernos de Etnología y Etnografía de Navarra 9(25):47-51

Publisher's Note Springer Nature remains neutral with regard to jurisdictional claims in published maps and institutional affiliations. 